\title{
Hydrographic conditions along the western Iberian margin during marine isotope stage 2
}

\author{
A. H. L. Voelker and L. de Abreu \\ Unidade Geologia Marinha, Laboratorio Nacional de Energia e Geologia, Estrada da Portela, 2721-866 Amadora, \\ Portugal (avoelker@softhome.net; luciaabreu@yahoo.com) \\ CIMAR Associate Laboratory, Rua dos Bragas 289, 4050-123 Porto, Portugal
}

\section{J. Schönfeld}

Leibniz Institute of Marine Sciences at University of Kiel (IFM-GEOMAR), Dienstgebäude Ostufer, Wischhofstraße 1-3, D-24148 Kiel, Germany

\section{H. Erlenkeuser} Leibniz Labor für Altersbestimmung und Isotopenforschung, Universität Kiel, Max-Eyth-Straße 11, D-24118 Kiel,
Germany

\section{F. Abrantes \\ Unidade Geologia Marinha, Laboratorio Nacional de Energia e Geologia, Estrada da Portela, 2721-866 Amadora, Portugal}

[1] The surface water hydrography along the western Iberian margin, as part of the North Atlantic's eastern boundary upwelling system, consists of a complex, seasonally variable system of equatorward and poleward surface and subsurface currents and seasonal upwelling. Not much information exists to ascertain if the modern current and productivity patterns subsisted under glacial climate conditions, such as during marine isotope stage (MIS) 2, and how North Atlantic meltwater events, especially Heinrich events, affected them. To help answer these questions we are combining stable isotope records of surface to subsurface dwelling planktonic foraminifer species with sea surface temperature and export productivity data for four cores distributed along the western and southwestern Iberian margin (MD95-2040, MD952041, MD99-2336, and MD99-2339). The records reveals that with the exception of the Heinrich events and Greenland Stadial (GS) 4 hydrographic conditions along the western Iberian margin were not much different from the present. During the Last Glacial Maximum (LGM), subtropical surface and subsurface waters penetrated poleward to at least $40.6^{\circ} \mathrm{N}$ (site MD95-2040). Export productivity was, in general, high on the western margin during the LGM and low in the central Gulf of Cadiz, in agreement with the modern situation. During the Heinrich events and GS 4, on the other hand, productivity was high in the Gulf of Cadiz and suppressed in the upwelling regions along the western margin where a strong halocline inhibited upwelling. Heinrich event 1 had the strongest impact on the hydrography and productivity off Iberia and was the only period when subarctic surface waters were recorded in the central Gulf of Cadiz. South of Lisbon $\left(39^{\circ} \mathrm{N}\right)$, the impact of the other Heinrich events was diminished, and not all of them led to a significant cooling in the surface waters. Thus, climatic impacts of Heinrich events highly varied with latitude and the prevailing hydrographic conditions in this region.

Components: 17,824 words, 12 figures, 8 tables.

Keywords: Iberian margin; Last Glacial Maximum; Heinrich events; planktonic foraminifer; stable isotopes; productivity. 
Index Terms: 4901 Paleoceanography: Abrupt/rapid climate change (1605); 4926 Paleoceanography: Glacial; 4964 Paleoceanography: Upwelling (4279).

Received 4 May 2009; Revised 1 October 2009; Accepted 6 October 2009; Published 1 December 2009.

Voelker, A. H. L., L. de Abreu, J. Schönfeld, H. Erlenkeuser, and F. Abrantes (2009), Hydrographic conditions along the western Iberian margin during marine isotope stage 2, Geochem. Geophys. Geosyst., 10, Q12U08, doi:10.1029/ 2009GC002605.

Theme: Circum-Iberia Paleoceanography and Paleoclimate: What Do We Know?

Guest Editors: F. Abrantes, C. Ruehlemann, M. F. Sánchez-Goñi, and A. Voelker

\section{Introduction}

[2] Because of the high productivity in their upwelling plumes and filaments eastern boundary systems play an important role in regulating atmospheric greenhouse gas concentrations by sequestering carbon and exporting it to the sediment [Berger et al., 1989]. The western Iberian margin is the northernmost section of the NW African/ Canary/Iberian upwelling system. Because the Iberian Peninsula extends up to $43.5^{\circ} \mathrm{N}$ it is also within the latitudes in which melting icebergs deposited their debris during glacial times [Ruddiman, 1977; Hemming, 2004]. The major ice-rafting events during the last glacial cycle were the Heinrich events [Heinrich, 1988; Bond et al., 1992] that caused abrupt and strong drops in sea surface temperature (SST) on the Portuguese margin [Bard et al., 2000; de Abreu et al., 2003; Salgueiro et al., 2009] and enabled the Polar Front to advance into these latitudes [Eynaud et al., 2009]. Due to the freshwater capping in the North Atlantic's deep convection areas these events had also a strong impact on the Atlantic Meridional Overturning Circulation (AMOC) leading to a significant reduction or even shutdown [Zahn et al., 1997; Schönfeld et al., 2003; McManus et al., 2004]. The changes in AMOC strength had also consequences for surface water productivity leading to a $50 \%$ reduction of the plankton stock, in agreement with observations by Nave et al. [2007]. This was caused by the shoaling of the winter mixed layer and its separation from the nutrient-rich deeper waters by the strong halocline in the open North Atlantic [Schmittner, 2005]. For the Iberian upwelling system the model results of Schmittner [2005] indicate, on the other hand, increased productivity along with the spin down of the AMOC linked to stronger upwelling of nutrient-rich subsurface waters. Since paleorecords indicate the presence of melting icebergs and thus most likely also the establishment of a strong halocline for the Portuguese margin [Bard et al., 2000; de Abreu et $a l ., 2003]$ a paleoproductivity increase, as predicted by Schmittner [2005], needs to be proven.

[3] During the Last Glacial Maximum (LGM; 1923 cal ka BP following [Mix et al., 2001]), the prevailing winds caused stronger and persistent upwelling and thus increased productivity in the upwelling systems off Portugal and NW Africa [Sarnthein et al., 1988; Abrantes, 1991, 1992; Pailler and Bard, 2002]. Based on the recent SST reconstruction for the LGM [MARGO Project Members, 2009] SSTs off Portugal were $2-4^{\circ} \mathrm{C}$ colder during summer and south of about $40^{\circ} \mathrm{N}$ also during winter, while north of this latitude cooling during winter was stronger $\left(4-6^{\circ} \mathrm{C}\right)$. In general, SST dropped more in the North Atlantic's eastern than western basin [MARGO Project Members, 2009]. Although the GLAMAP project used a slightly different time slice definition, the amount of cooling was in a similar range with a pronounced temperature gradient between 40 and $45^{\circ} \mathrm{N}$ [Pflaumann et al., 2003]. Nevertheless, the Polar Front was always located north of the Iberian Peninsula during the LGM [Pflaumann et al., 2003; Eynaud et al., 2009]. South of the Peninsula the Azores Front, which today marks the northern boundary of the subtropical gyre per se, extended eastward into the Gulf of Cadiz [Rogerson et al., 2004] allowing subtropical surface waters to access the nearshore region off Portugal [Eynaud et al., 2009]. Understanding the hydrographic conditions during the LGM is essential because the LGM is one of the case studies used for data-model comparison and thus in evaluating the robustness of climate models [Kageyama et al., 2006; Braconnot et al., 2007; Otto-Bliesner et al., 2007]. With the tendency of nesting regional climate models into global models to better understand regional 
responses to and impacts of glacial climate changes [Kjellström et al., 2009; E. Kjellström et al., Simulated climate conditions in Europe during a MIS 3 stadial, submitted to Boreas, 2009], it becomes even more important to refine regional paleoclimate reconstructions. More recently, Flückiger et al. [2008] showed that the strength of regional climate response is even dependent on the season with winter temperature changes being the dominant factor in the North Atlantic region.

[4] Here we use data from four core sites covering the latitudes from 40.6 to $35.8^{\circ} \mathrm{N}$ and modern hydrographic conditions ranging from the seasonal upwelling regime along the western margin to the oligotrophic Gulf of Cadiz to reconstruct hydrographic and productivity conditions during the interval from 31 to 13 calendar (cal) ka BP. Proxy data employed in this study is a suite of planktonic foraminifer stable isotope records combined with SST and export productivity estimates. The selected time interval encompasses the LGM and Heinrich events 1 to 3 allowing us to evaluate how boundary conditions during these specific periods affected the structure of the upper water column, whether the response among the Heinrich events differed, and how productivity changed due to the prevailing hydrographic conditions. Special attention was paid to conditions in the subsurface layer because (1) the subsurface waters are the nutrient source sustaining productivity either by upwelling or by deep winter mixing and (2) little is known about them and their potential flow direction, so that they were disregarded in the interpretation of climate models.

\section{Hydrographic Settings}

[5] The western Iberian seas are characterized by a typical eastern boundary current system with currents and counter currents that shape the margin's hydrography during the different seasons. In addition, the western and southern coasts are affected by upwelling typically from late May/early June to late September/early October [Haynes et al., 1993]. Two currents, the Portugal Current (PC) per se and the Azores Current (AzC), both of which are branches of the Gulf Stream/North Atlantic Current system, dominate the large-scale circulation off the western Iberian Peninsula.

[6] The PC is the major part of the Portugal current system, which consists of the PC per se in the open ocean and the Portugal Coastal Current (PCC) along the slope. The PC advects surface and subsurface waters slowly southward [Perez et al., 2001; van Aken, 2001] and is centered west of $10^{\circ} \mathrm{W}$ in winter (Figure 1a [Peliz et al., 2005]). The subsurface component of the PC is the Eastern North Atlantic Central Water (ENACW) of subpolar (sp) origin, which is formed by winter cooling in the eastern North Atlantic [McCartney and Talley, 1982]. The PCC exists only during the upwelling season and is a jet-like upper slope current, which is driven by the northerly winds and transports the cold, less saline upwelled waters southward [Fiúza, 1984; Alvarez-Salgado et al., 2003]. Around Cape São Vicente (Figure 1a) a part of this jet turns eastward and enters the Gulf of Cadiz [Sanchez and Relvas, 2003]. In the Gulf of Cadiz, it flows along the upper slope toward the Strait of Gibraltar [Garcia-Lafuente et al., 2006], potentially interacting with the local upwelling off Cape Santa Maria [Sanchez and Relvas, 2003]. Further downstream, the slope current either forms an anticyclonic meander in the eastern Gulf of Cadiz or enters the Mediterranean Sea as Atlantic inflow [Sanchez and Relvas, 2003; Garcia-Lafuente et al., 2006].

[7] The $\mathrm{AzC}$ and the associated subtropical front reveal large meanders between 35 and $37^{\circ} \mathrm{N}$ in the eastern North Atlantic (Figure 1a). While most of the $\mathrm{AzC}$ recirculates southward, its eastern branch flows into the Gulf of Cadiz [Johnson and Stevens, 2000; Vargas et al., 2003; Peliz et al., 2005], where it feeds the offshore flow (Figure 1). During winter some of the $\mathrm{AzC}$ current water recirculates from the Gulf of Cadiz around Cape S. Vicente to the SW Iberian margin [Peliz et al., 2005] (Figures 1a and $1 \mathrm{~b}$ ). Ocean models indicate that the flow from the $\mathrm{AzC}$ into the Gulf is quite significant [Penduff et al., 2001] and link the existence of the current itself to the entrainment of surface to subsurface waters into the Mediterranean Outflow waters [ $\mathrm{Jia}$, 2000; Özgökmen et al., 2001]. Between October and March, when the surface water component of the Iberian Poleward Current (IPC; Figure 1), sometimes also referred to as Portugal Coastal Countercurrent, becomes a prominent feature in the circulation off western Iberia, the thermal subtropical front (at $\sim 17^{\circ} \mathrm{C}$ ) is shifted northward and reaches the SW Iberian margin [Pingree et al., 1999]. Peliz et al. [2005] observe a recurrent frontal system, the Western Iberia Winter Front, which follows the thermal subtropical front in the south, but then meanders northward and separates the IPC from the PC (Figure 1a). The IPC reaches into a depth of $400 \mathrm{~m}$. It transports warm and saltrich waters of subtropical origin [Frouin et al., 1990; Haynes and Barton, 1990] and can be traced 

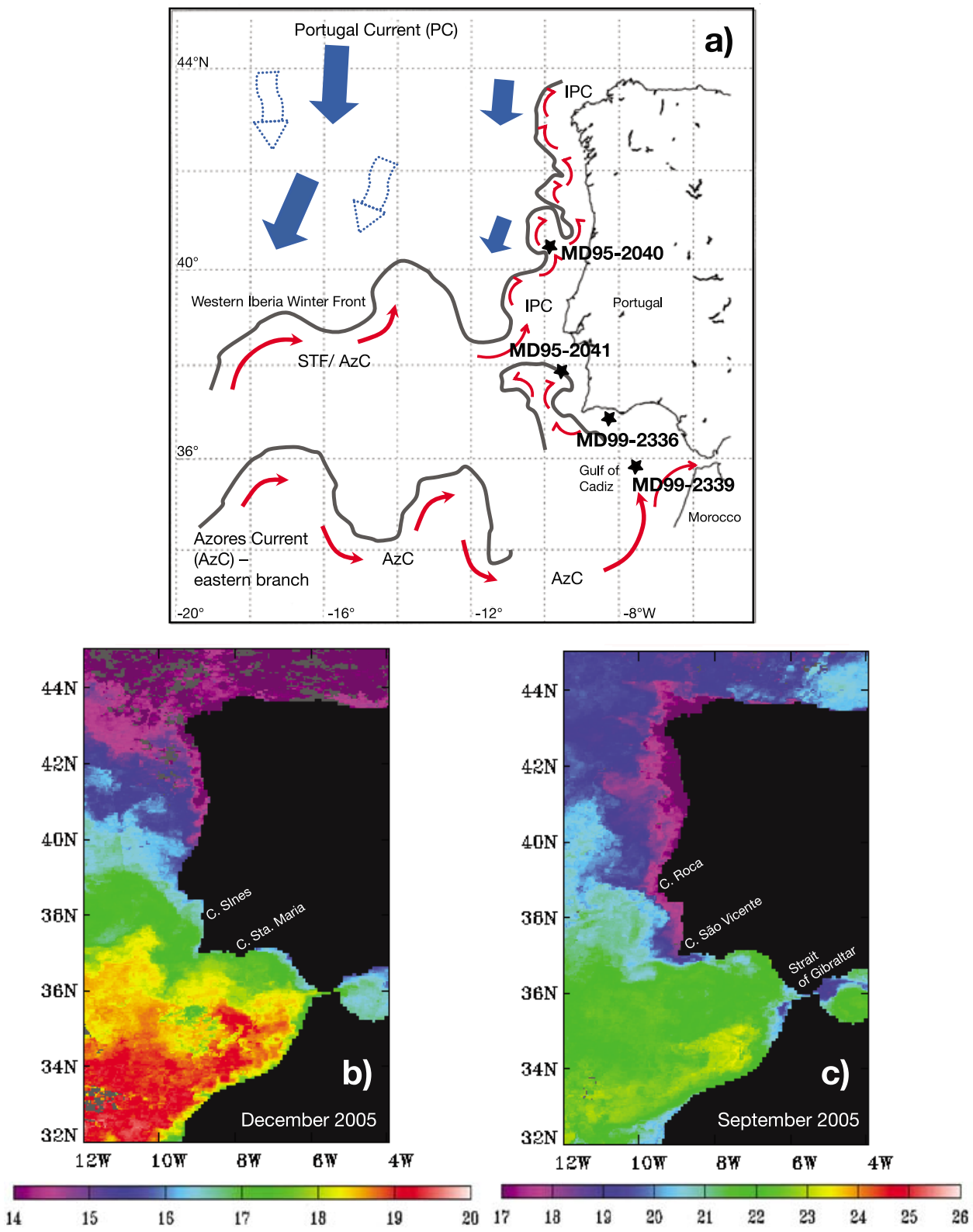

Figure 1. (a) Hydrographic situation during winters off Portugal with core sites (modified from Peliz et al. [2005], copyright 2005, with permission from Elsevier). STF, subtropical front; IPC, Iberian Poleward Current. MODIS Aqua Satellite based sea surface temperatures (http://poet.jpl.nasa.gov) for (b) December and (c) September 2005. The warmer SST during December in the Gulf of Cadiz highlights the Azores Current waters. During September the colder SST along the western margin and stretching offshore indicate the upwelling regions and filaments. Note two different SST scales.

into the Bay of Biscaye. The subsurface or undercurrent part of the IPC conveys ENACW of subtropical (st) origin poleward year round.

[8] $\mathrm{ENACW}_{\text {st }}$, which is formed by strong evaporation and winter cooling along the Azores front [Fiúza, 1984; Rios et al., 1992], is poorly ventilated, warmer and saltier than its subpolar counter part. The northward flow of ENACW st $_{\text {in }}$ the upper 100 to $250 \mathrm{~m}$ is sometimes also referred to as the
Portugal Coastal Under Current [Perez et al., 2001]. While the ENACW $\mathrm{E}_{\text {st }}$ forms a salinity maximum around $100 \mathrm{~m}$, the lower boundary of the ENACW is indicated by a salinity minimum between 450 and $500 \mathrm{~m}$ (Figure 2) [Fiúza et al., 1998]. ENACW is the source for the water upwelled during May to September and in general ENACW $\mathrm{Et}_{\mathrm{st}}$ is upwelled south of $40^{\circ} \mathrm{N}$ and $\mathrm{ENACW}_{\mathrm{sp}}$ north of $45^{\circ} \mathrm{N}$. In between either water mass can be upwelled depending on the strength of the wind forcing. 
A) near site MD95-2040

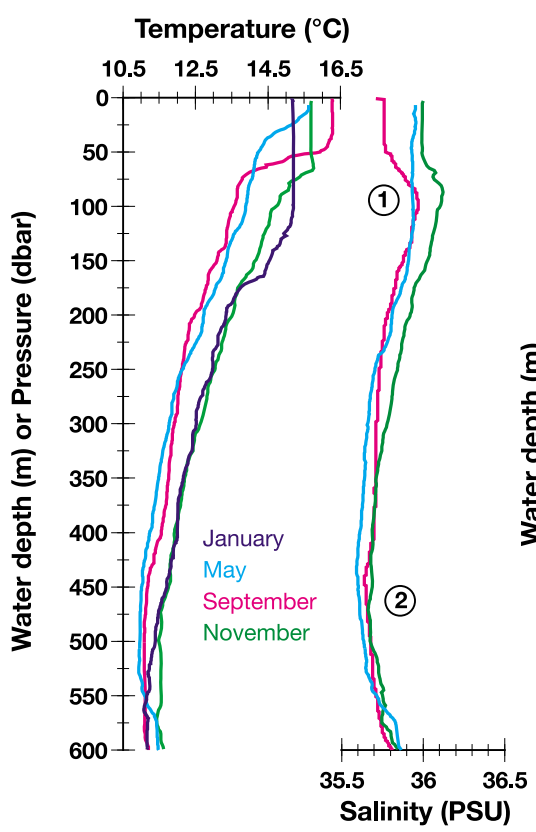

B) near sites MD95-2041, MD99-2336 and MD99-2339

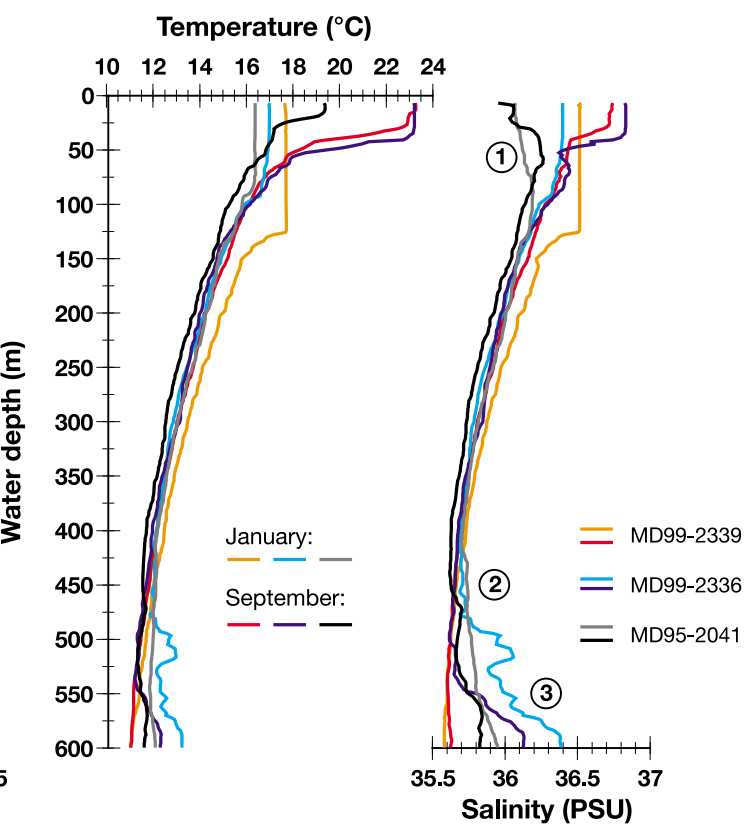

Figure 2. CTD profiles for the upper $600 \mathrm{~m}$ close to the studied core sites. (a) Profiles close to site MD95-2040: January 1992, FHeinicke profile; May 1993 and November 1993, profiles acquired during the MORENA project [Fiúza et al., 1998]; September 1994, profile from the FLUXPOR campaign. (b) Profiles off the southwestern and southern margin acquired within the CANIGO project [Ambar et al., 2002]. January 1998 profiles are from stations 45, 94, and 19, and September 1997 data from stations 27, 81, and 177. All hydrographic data were provided by Isabel Ambar (Instituto de Oceanografia, Universidade de Lisboa). Number 1 indicates the salinity maximum of the subtropical ENACW, number 2 indicates the salinity minimum associated with the subpolar ENACW, and number 3 indicates the upper core of the Mediterranean Outflow Water.

[9] Upwelling along the western margin is driven by northward displacement of the Azores highpressure cell and the resulting northerly winds, while westerly winds cause upwelling along the southern margin. Intense upwelling on the western margin is linked to topographic features like Cape Roca and Cape S. Vicente (Figure 1) or submarine canyons [Sousa and Bricaud, 1992]. From July onward the filaments can extend up to $250 \mathrm{~km}$ offshore north of Lisbon (Figure 1c) [Sousa and Bricaud, 1992; Haynes et al., 1993]. The Lisbon plume, which is linked to Cape Roca, can either extend westward or southward toward Cape Sines (Figure 1c). During intense upwelling events, the filament off Cape S. Vicente extends southward and is fed by a PCC overshooting the Cape. The most persistent feature, however, is an eastward extension along the southern Portuguese shelf break and slope [Relvas and Barton, 2002] (Figure 1c). When westerly winds prevail, the waters from the Cape S. Vicente filament merge with locally upwelled waters [Sousa and Bricaud, 1992; Relvas and Barton, 2002], commonly a plume off Cape Santa Maria (Figure 1). Upwelled waters can then affect the whole region between 9 and $8.5^{\circ} \mathrm{W}$ down to $36.5^{\circ} \mathrm{N}$ [see Sanchez and Relvas, 2003, Figure 11]. In addition, easterly winds frequently induce upwelling on the African side of the Strait of Gibraltar [Folkard et al., 1997; Stanichny et al., 2005; Peliz et al., 2009]. During the wind-forcing period this upwelling plume is advected into the Gulf of Cadiz and can propagate for about $100 \mathrm{~km}$ into the eastern Gulf [Stanichny et al., 2005]. When the winds weaken, the plume gets advected into the Alboran Sea (Figure 1c).

\section{Material and Methods}

[10] This study involves four core sites (Table 1 and Figure 1): Calypso piston cores MD95-2040 and MD95-2041, which were retrieved on the western Portuguese margin during the first IMAGES cruise on $\mathrm{R} / \mathrm{V}$ Marion Dufresne in 1995 [Bassinot and Labeyrie, 1996], and cores MD99-2336 and MD99-2339, which were cored in the Gulf of Cadiz during leg 5 of the IMAGES GINNA cruise in 1999 [Labeyrie et al., 2003]. All 


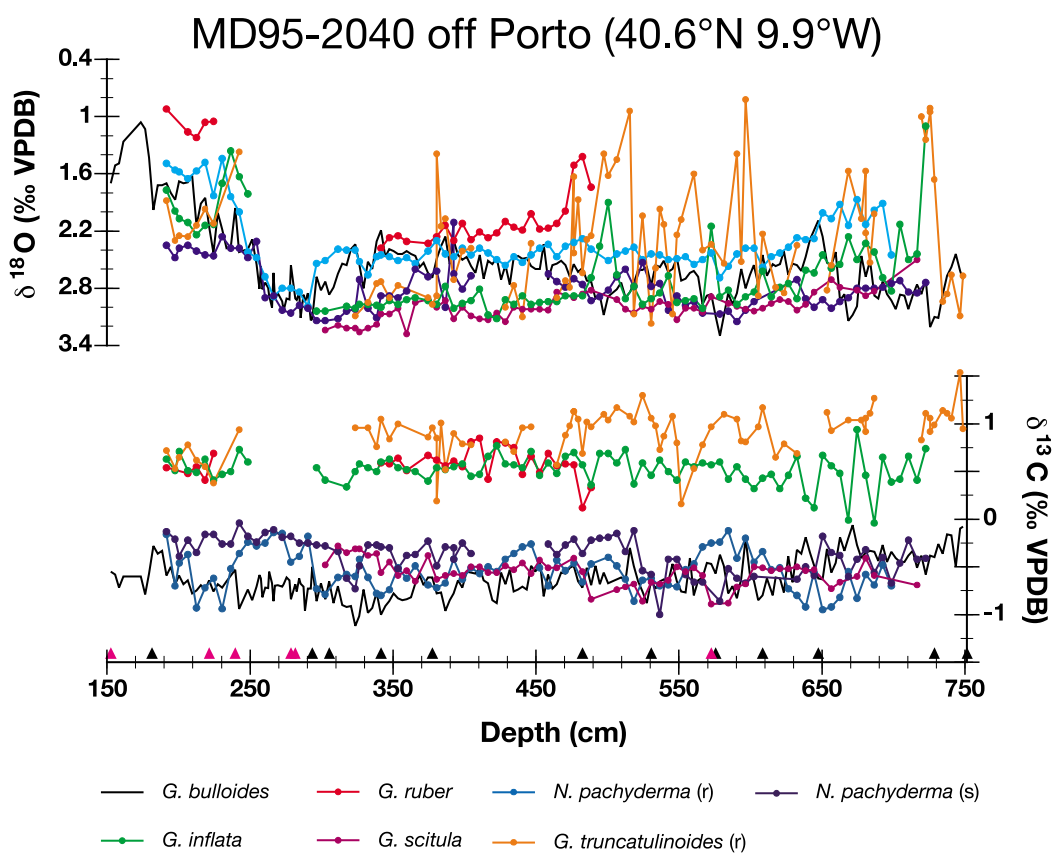

Figure 3. Planktonic foraminifer stable isotope records versus depth of core MD95-2040. G. bulloides record is shown in black, G. ruber white is shown in red, N. pachyderma (r) is shown in light blue, N. pachyderma (s) is shown in dark blue, G. inflata is shown in green, G. scitula is shown in purple, and G. truncatulinoides $(\mathrm{r})$ is shown in orange. Black and magenta triangles above the depth scale indicate positions of age control points based on tuning to the GISP2 $\delta^{18} \mathrm{O}$ record and calibrated ${ }^{14} \mathrm{C}$ ages, respectively (Table 5).

\section{MD95-2041 off Sines $\left(37.8^{\circ} \mathrm{N} 9.5^{\circ} \mathrm{W}\right)$}

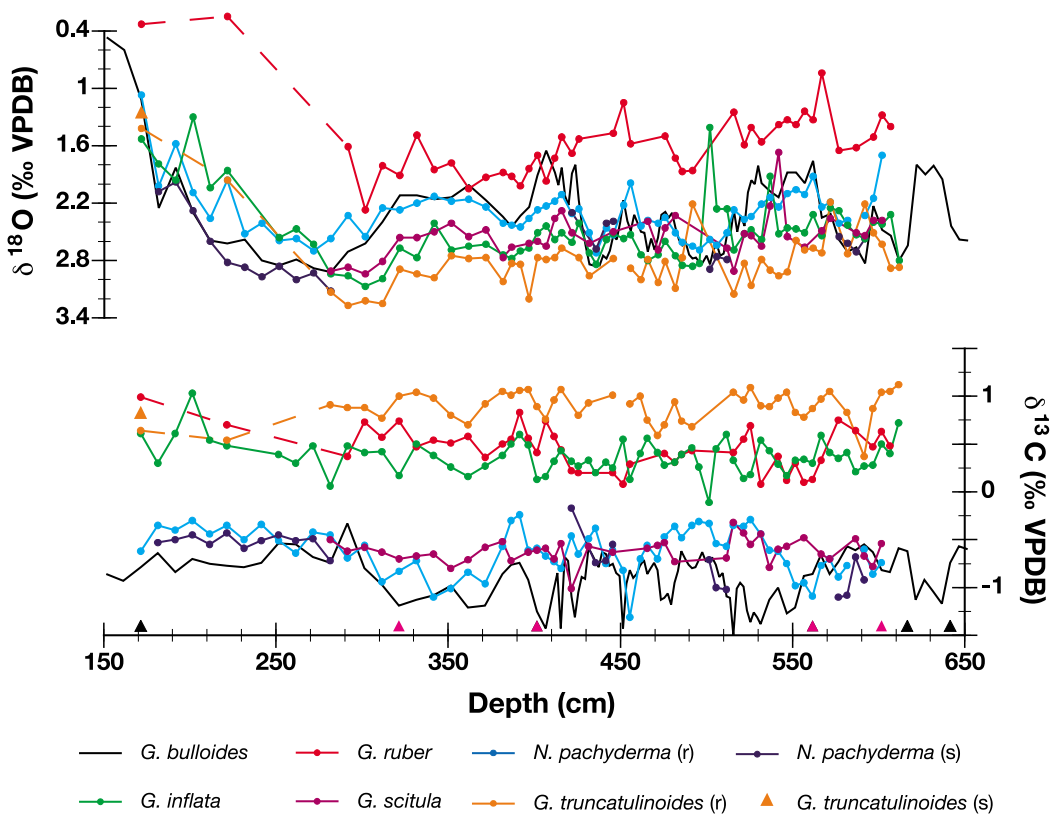

Figure 4. Planktonic foraminifer stable isotope records versus depth of core MD95-2041. G. bulloides record is shown in black, G. ruber white is shown in red, N. pachyderma (r) is shown in light blue, N. pachyderma (s) is shown in dark blue, G. inflata is shown in green, G. scitula is shown in purple, and G. truncatulinoides $(\mathrm{r})$ is shown in orange. A single data point measurement in G. truncatulinoides (s) at the onset of the Boelling is shown as orange triangle. Black and magenta triangles above the depth scale indicate positions of age control points based on tuning to the GISP2 $\delta^{18} \mathrm{O}$ record and calibrated ${ }^{14} \mathrm{C}$ ages, respectively (Table 6). 


\section{MD99-2336, Faro Drift $\left(36.7^{\circ} \mathrm{N} 8.3^{\circ} \mathrm{W}\right)$}
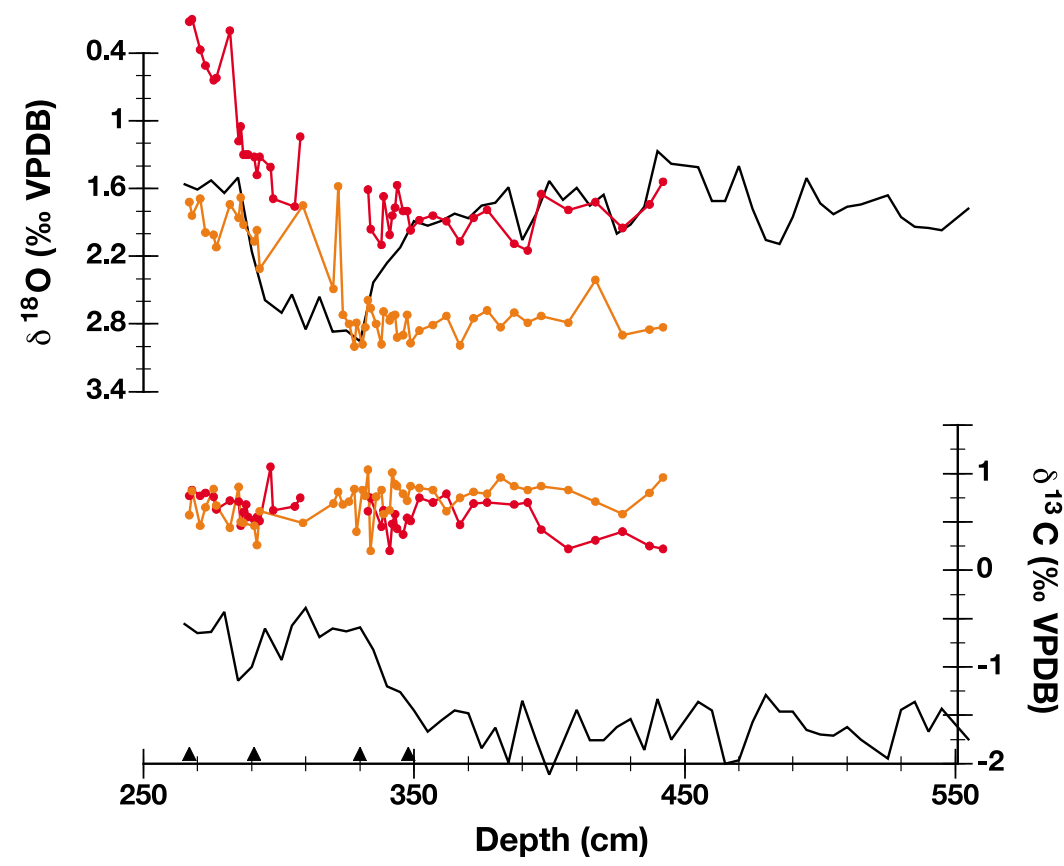

G. bulloides $\rightarrow$ G. ruber $\multimap$ G. truncatulinoides $(r)$

Figure 5. Planktonic foraminifer stable isotope records versus depth of core MD99-2336. G. bulloides record is shown in black, G. ruber white is shown in red, and G. truncatulinoides (r) is shown in orange. Black triangles above the depth scale indicate positions of used age control points (Table 7).

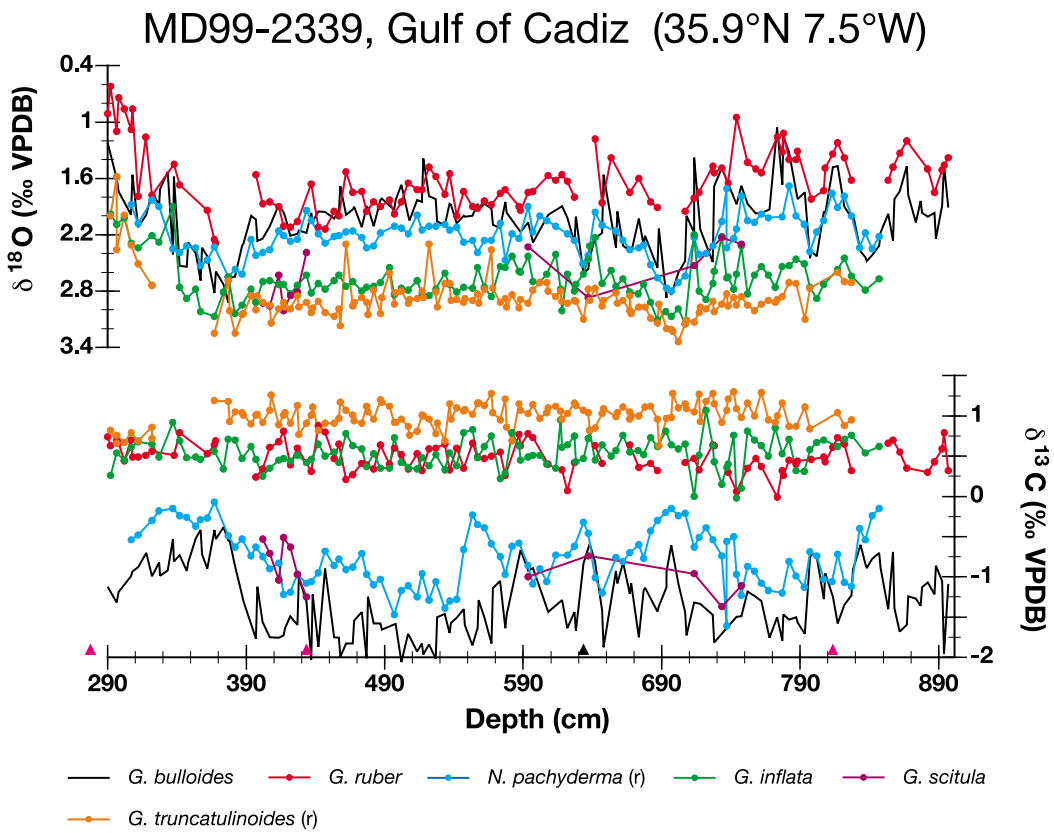

Figure 6. Planktonic foraminifer stable isotope records versus depth of core MD99-2339. G. bulloides record is shown in black, G. ruber white is shown in red, N. pachyderma (r) is shown in light blue, G. inflata is shown in green, G. scitula is shown in purple, and G. truncatulinoides (r) is shown in orange. Black and magenta triangles above the depth scale indicate positions of age control points based on tuning to the GISP2 $\delta^{18} \mathrm{O}$ record and calibrated ${ }^{14} \mathrm{C}$ ages, respectively (Table 8 ). 
Table 1. Studied Core Sites

\begin{tabular}{cccc}
\hline Core & $\begin{array}{c}\text { Longitude } \\
\left({ }^{\circ} \mathrm{N}\right)\end{array}$ & $\begin{array}{c}\text { Latitude } \\
\left({ }^{\circ} \mathrm{W}\right)\end{array}$ & $\begin{array}{c}\text { Water Depth } \\
(\mathrm{m})\end{array}$ \\
\hline MD95-2040 & 40.582 & 9.862 & 2465 \\
MD95-2041 & 37.833 & 9.518 & 1123 \\
MD99-2336 & 36.717 & 8.259 & 690 \\
MD99-2339 & 35.886 & 7.528 & 1170 \\
\hline
\end{tabular}

cores are from high-sedimentation areas, so that their data sets yield decadal- and centennial-scale climate records even though sample spacing varies between 1 and $10 \mathrm{~cm}$, respectively (Figures $3-6$ ). Modern $\delta^{18} \mathrm{O}$ values in water samples $(\delta \mathrm{w}$; Table 2$)$ were measured in water samples from a transect across the Azores front at about $20^{\circ} \mathrm{W}$ and from a station in the Gulf of Cadiz. These hydrographic stations were performed on $\mathrm{R} / \mathrm{V}$ Poseidon cruise PO334 in March 2006 [Schulz et al., 2006].

[11] The oxygen isotope ratios in the water samples were measured at the Leibniz Laboratory, Kiel, on the Finnigan Delta E mass spectrometer, which is coupled to an equilibrium bath. Reproducibility is better than $\pm 0.07 \%$ o and values are given as \%o SMOW. Foraminifer based stable isotope ratios were measured in up to eight different planktonic species and the details for each core and species are summarized in Table 3. Hydrographic implications associated with each foraminifer species and its estimated living depths, which are based on the hydrographic profiles compiled in Figure 2, are listed in Table 4. Globorotalia inflata and Globorotalia truncatulinoides specimens were picked from the fraction $>250 \mu \mathrm{m}$ but their diameter is usually larger than $315 \mu \mathrm{m}$, so that all species were picked from the size fraction with their respective maximum abundance. Furthermore, these size fractions contain the postgametogenic specimens minimizing potential isotopic offsets due to the absence of the gametogenic crust in species such as $N$. pachyderma or $G$. truncatulinoides [Lohmann, 1995; Hillaire-Marcel et al., 2001; Simstich et al., 2003; Lončarić et al., 2006]. The Globigerina bulloides $\delta^{18} \mathrm{O}$ record of core MD952040 is from de Abreu et al. [2003] and those from cores MD95-2041 and MD99-2336 were generated by L. de Abreu and J. Schönfeld, respectively. The G. bulloides record of core MD99-2339 is from Voelker et al. [2006] (Figure 6). Isotope measurements in the other species were funded by a Paleostudies grant from Bremen university to A. Voelker (core MD95-2040 and parts of core MD95-2041) and by the Portuguese project "MOWFADRI." Most of the isotope samples were measured in the stable isotope laboratory at Marum, University Bremen, where they were either analyzed on a Finnigan MAT 251 mass spectrometer (samples funded by Paleostudies grant) or on a Finnigan MAT 252 mass spectrometer, both of which have a long-term precision of $\pm 0.07 \%$ or for $\delta^{18} \mathrm{O}$ and $\pm 0.05 \%$ or $\delta^{13} \mathrm{C}$. Samples measured at Geomar (Kiel) were run through a Finnigan MAT 252 mass spectrometer with an automated Kiel Carbonate Preparation line. External reproducibility of the in-house carbonate standard (Solnhofen limestone) was $\pm 0.08 \%$ for $\delta^{18} \mathrm{O}$ and $\pm 0.04 \%$ for $\delta^{13} \mathrm{C}$ at the $1 \sigma$ level. At the Leibniz Laboratory for Radiometric Dating and Stable Isotope Research at Kiel University analyses were performed with the Carbo Kiel (Kiel 1) device coupled to a Finnigan MAT 251 mass spectrometer with a precision of $\pm 0.07 \%$ for $\delta^{18} \mathrm{O}$ and $\pm 0.04 \%$ for $\delta^{13} \mathrm{C}$ for the Solnhofen limestone standard. The G. bulloides samples and a few additional ones of core MD95-2040 were measured in the Godwin laboratory at Cambridge university either on a VG Isotech SIRA-Series II mass spectrometer or a PRISM mass spectrometer, both with an analytical precision for the Carrara Marble standard of $\pm 0.08 \%$ for $\delta^{18} \mathrm{O}$ and of

Table 2. Values of $\delta^{18} \mathrm{O}$ in Water Samples From the Eastern North Atlantic

\begin{tabular}{|c|c|c|c|c|c|c|}
\hline & \multicolumn{6}{|c|}{$\delta \mathrm{w} \%$ SMOW } \\
\hline & $\begin{array}{r}32^{\circ} 58.83^{\prime} \mathrm{N} \\
19^{\circ} 59.84^{\prime} \mathrm{W} \\
\operatorname{POS} 334-67\end{array}$ & $\begin{array}{r}34^{\circ} 59.97^{\prime} \mathrm{N} \\
19^{\circ} 59.96^{\prime} \mathrm{W} \\
\text { POS334-68 }\end{array}$ & $\begin{array}{r}36^{\circ} 19.97^{\prime} \mathrm{N} \\
20^{\circ} 00.04^{\prime} \mathrm{W} \\
\operatorname{POS} 334-69\end{array}$ & $\begin{array}{r}37^{\circ} 05.47^{\prime} \mathrm{N} \\
20^{\circ} 00.23^{\prime} \mathrm{W} \\
\operatorname{POS} 334-70\end{array}$ & $\begin{array}{c}38^{\circ} 23.01^{\prime} \mathrm{N} \\
20^{\circ} 00.18^{\prime} \mathrm{W} \\
\text { POS334-71 }\end{array}$ & $\begin{array}{r}36^{\circ} 00.29^{\prime} \mathrm{N} \\
08^{\circ} 29.90^{\prime} \mathrm{W} \\
\text { POS334-72 }\end{array}$ \\
\hline $10 \mathrm{~m}$ & 1.04 & 0.95 & 0.96 & 0.83 & 0.87 & 0.93 \\
\hline $50 \mathrm{~m}$ & 1.03 & 0.99 & 0.95 & 0.78 & 0.89 & 0.87 \\
\hline $100 \mathrm{~m}$ & $1.02^{\mathrm{a}}$ & 0.97 & 0.95 & 0.81 & 0.79 & 0.91 \\
\hline $150 \mathrm{~m}$ & & 0.94 & 0.81 & 0.82 & 0.88 & 0.95 \\
\hline $250 \mathrm{~m}$ & 0.90 & 0.82 & 0.75 & 0.74 & 0.64 & 0.68 \\
\hline $400 \mathrm{~m}$ & 0.67 & 0.55 & 0.58 & 0.61 & 0.53 & 0.57 \\
\hline $600 \mathrm{~m}$ & 0.51 & 0.54 & 0.52 & 0.53 & 0.50 & 0.55 \\
\hline
\end{tabular}

\footnotetext{
${ }^{\mathrm{a}}$ Sample from $120 \mathrm{~m}$ water depth.
} 
Table 3. Details for the Planktonic Foraminifer Stable Isotope Analyses

\begin{tabular}{|c|c|c|c|c|}
\hline Core & Species & $\begin{array}{l}\text { Size Fraction } \\
\quad(\mu \mathrm{m})\end{array}$ & $\begin{array}{c}\text { Number of } \\
\text { Specimens Analyzed }\end{array}$ & $\begin{array}{l}\text { Laboratory for Stable } \\
\text { Isotope Analyses }\end{array}$ \\
\hline \multirow[t]{7}{*}{ MD95-2040 } & G. bulloides & $250-355$ & 30 & Godwin lab, Cambridge \\
\hline & G. ruber white & $>250$ & $17-21$ & Marum Bremen $^{\mathrm{a}}$ \\
\hline & N. pachyderma $(\mathrm{d})$ & $150-250$ & $25-30$ & Marum Bremen $^{\mathrm{a}}$ \\
\hline & N. pachyderma (s) & $150-250$ & $25-44$ & Marum Bremen ${ }^{a}$ \\
\hline & G. inflata & $>250$ & 8 & Marum Bremen \\
\hline & G. scitula & $>250$ or $>150$ & $20-30$ & Marum Bremen \\
\hline & G. truncatulinoides (d) & $>250$ & $3-7$ & Marum Bremen \\
\hline \multirow[t]{8}{*}{ MD95-2041 } & G. bulloides & $>250$ & 30 & Godwin lab, Cambridge \\
\hline & G. ruber white & $>250$ & $11-18$ & Marum Bremen \\
\hline & N. pachyderma $(\mathrm{d})$ & $150-250$ & $22-27$ & Marum Bremen \\
\hline & N. pachyderma (s) & $150-250$ & $20-25$ & Marum Bremen \\
\hline & G. inflata & $>250$ & $7-11$ & Marum Bremen \\
\hline & G. scitula & $>250$ & $21-26$ & Marum Bremen \\
\hline & G. truncatulinoides (d) & $>250$ & $2-12$ & Marum Bremen \\
\hline & G. truncatulinoides (s) & $>250$ & 12 & Marum Bremen \\
\hline \multirow{3}{*}{ MD99-2336 } & G. bulloides & $>250$ & $2-15$ & Geomar Kiel \\
\hline & G. ruber white & $>250$ & $6-16$ & Marum Bremen \\
\hline & G. truncatulinoides (d) & $>250$ & $2-6$ & Marum Bremen \\
\hline \multirow[t]{6}{*}{ MD99-2339 } & G. bulloides & $>250$ & $7-25$ & Leibniz Kiel, Marum Bremen \\
\hline & G. ruber white & $>250$ & $5-24$ & Leibniz Kiel, Marum Bremen \\
\hline & N. pachyderma $(\mathrm{d})$ & $150-250$ & $22-30$ & Leibniz Kiel \\
\hline & G. inflata & $>250$ & $5-20$ & Leibniz Kiel \\
\hline & G. scitula & $>250$ or $>150$ & $10-16,13-30$ & Leibniz Kiel \\
\hline & G. truncatulinoides (d) & $>250$ & $1-5$ & Leibniz Kiel \\
\hline
\end{tabular}

${ }^{\mathrm{a}}$ Two to three samples were measured in the Godwin lab, Cambridge, in 2003.

$\pm 0.06 \%$ or $\delta^{13} \mathrm{C}$. At all laboratories, the results were calibrated with the NBS 19 standard and the isotope values are reported on the VPDB (Vienna PDB) scale.

[12] The $\delta^{18} \mathrm{O}$ value of foraminiferal carbonate generally diverges from the equilibrium value for nonbiogenic carbonate. This so-called vital effect is species-dependent, but also varies with shell size [Spero et al., 1997; Peeters et al., 2002], temperature, and region. No data exists for the Iberian margin, so that we compiled global data in Table 4. The $\delta^{18} \mathrm{O}$ deviations described by Wilke et al. [2009] for G. ruber white, G. bulloides and $G$. truncatulinoides in the Canary Island region (see Table 4) are those hydrographically closest to the southwestern Iberian margin. We decided, however, not to correct our foraminiferal $\delta^{18} \mathrm{O}$ data because Wilke et al. [2009] do not provide deviations for all the species analyzed. Furthermore, the compiled published values can vary significantly for one species (e.g., G. bulloides or G. inflata, Table 4). The Heinrich events were periods of significant cooling at the Iberian margin [Eynaud et al., 2009], so that correctly one would also have to amend for varying temperature effects on the $\delta^{18} \mathrm{O}$ deviations through time. Also foraminifer $\delta^{13} \mathrm{C}$ values, which reflect nutrient concentrations in the ambient seawater [Broecker and Peng,
1982], deviate from $\delta^{13} \mathrm{C}_{\mathrm{DIC}}$ (DIC: dissolved inorganic carbon) because of vital effects, temperature dependencies and the carbonate ion effect [Ortiz et al., 1996; Bemis et al., 1998; Kohfeld et al., 2000; Itou et al., 2001; Peeters et al., 2002; Wilke et al., 2006]. Foraminiferal $\delta^{13} \mathrm{C}$ is generally lighter than $\delta^{13} \mathrm{C}_{\text {DIC }}$ (Table 4) with G. bulloides showing the largest offset based on culture studies [Bemis et al., 2000]. Because no information is available for $N$. pachyderma (r) and $G$. truncatulinoides, the $\delta^{13} \mathrm{C}$ data shown in this study is not corrected to $\delta^{13} \mathrm{C}_{\mathrm{DIC}}$.

[13] Planktonic foraminifer census counts were done in splits of the fraction $>150 \mu \mathrm{m}$ or the combination of fractions $>250 \mu \mathrm{m}$ and 150-250 $\mu \mathrm{m}$ (core MD99-2339) with the number of specimens counted in total exceeding 250. The census data was used to calculate SSTs and export productivity (Pexp) with the SIMMAX transfer function of [Pflaumann et al., 1996]. Following the recommendations of the MARGO project [Kucera et al., 2005], the modern analog data files are restricted to North Atlantic surface samples. They include new surface samples from the Portuguese margin and the Gulf of Cadiz [Salgueiro et al., 2008], resulting in a total of 1020 modern analogs for SST and 999 for Pexp [Salgueiro et al., 2009]. Modern analog temperatures for a water depth of $10 \mathrm{~m}$ were taken from the World Ocean Atlas 1998. The export 
Table 4. Living Preferences and Isotopic Deviations of the Studied Foraminifers

\begin{tabular}{|c|c|c|c|c|}
\hline Species & Living Depths & Hydrological Implications & Offset to $\delta^{18} \mathrm{O}_{\text {equil. }}$ & Offset to $\delta^{13} \mathrm{C}_{\mathrm{DIC}}$ \\
\hline \multicolumn{5}{|l|}{ Surface dweller } \\
\hline G. ruber white & upper $50 \mathrm{~m}$ & $\begin{array}{l}\text { mixed layer; associated } \\
\text { with Azores Current/Iberian } \\
\text { Poleward Current }{ }^{\mathrm{a}, \mathrm{b}, \mathrm{c}}\end{array}$ & $\begin{array}{l}-0.48 \text { to }-0.50 \%,{ }^{\mathrm{c}} \\
-0.20 \text { to }-0.41 \% \mathrm{~d}\end{array}$ & $+0.94 \% \mathrm{e}$ \\
\hline G. bulloides & upper $100 \mathrm{~m}$ & $\begin{array}{l}\text { upwelling }^{\mathrm{a}} \text {; associated with } \\
\text { Portugal Current }\end{array}$ & $\begin{array}{c}-0.05 \% 0,{ }^{\mathrm{c}}-0.40 \% 0,{ }^{\mathrm{f}} \\
-0.95 \%{ }^{\mathrm{g}}\end{array}$ & $-3.65 \%{ }^{\mathrm{h}}$ \\
\hline \multicolumn{5}{|l|}{ Deeper dweller } \\
\hline N. pachyderma (r) & upper $200 \mathrm{~m}$ & $\begin{array}{l}\text { (sub)thermocline water }{ }^{\mathrm{g}, \mathrm{i}, \mathrm{j}} \text {; } \\
\text { preupwelling to early upwelling }{ }^{\mathrm{i}, \mathrm{k}} \text {; } \\
\text { associated with Portugal Current }^{\mathrm{a}}\end{array}$ & $\begin{array}{l}-0.38 \% \text { at } 15^{\circ} \mathrm{C}, \\
-0.44 \% \text { at } 20^{\circ} \mathrm{C}, \\
-1.00 \%{ }^{1}\end{array}$ & \\
\hline N. pachyderma (s) & upper $200 \mathrm{~m}$ & $\begin{array}{l}\text { (sub)thermocline water }{ }^{\mathrm{g}, \mathrm{i}, \mathrm{j}} \\
\text { (sub)polar water associated } \\
\text { with meltwater events }\end{array}$ & $\begin{array}{l}-0.50 \%,{ }^{\mathrm{f}}-0.70 \\
\text { to }-0.90 \% \text { at } 6^{\circ} \mathrm{C}^{\mathrm{j}, \mathrm{m}}\end{array}$ & $-0.75 \% 0,{ }^{m}-1.00 \%{ }^{n}$ \\
\hline G. inflata & \multicolumn{2}{|c|}{$\begin{array}{r}\text { down to } 200 \mathrm{~m} \text { deep winter mixed layer }{ }^{\mathrm{o}} \text {; } \\
\text { associated with Portugal } \\
\text { or Azores Current }{ }^{\mathrm{a}}\end{array}$} & $\begin{array}{l} \pm 0 \% \text { at } 50 \mathrm{~m} \text { depth },{ }^{\mathrm{f}} \\
\quad+0.01 \text { to }+0.25 \% 0, \\
\quad-0.94 \% \mathrm{~d}\end{array}$ & $-1.55 \%{ }^{\mathrm{p}}$ \\
\hline G. scitula & $>100 \mathrm{~m}$ & $\begin{array}{l}\text { deep winter mixed layer; } \\
\text { associated with Azores Front }{ }^{\mathrm{q}}\end{array}$ & $-0.40 \%$ at $6^{\circ} \mathrm{C}^{\mathrm{m}}$ & $-1.10 \%$ at $6^{\circ} \mathrm{C}^{\mathrm{m}}$ \\
\hline G. truncatulinoides & $250-400 \mathrm{~m}$ & $\begin{array}{l}\text { below mixed layer }{ }^{\mathrm{c}, \mathrm{r}} \text {; } \\
\text { winter thermocline }{ }^{\mathrm{c}} \text {; ENACW }\end{array}$ & $\begin{array}{l}-0.09 \text { to }-0.11 \%,{ }^{\mathrm{c}} \\
-0.10 \text { to }+0.16 \%{ }^{\mathrm{d}}\end{array}$ & \\
\hline
\end{tabular}

${ }^{\mathrm{a}}$ Salgueiro et al. [2008], Iberian margin.

${ }^{\mathrm{b}}$ Ottens [1991], North Atlantic.

${ }^{\mathrm{c}}$ Wilke et al. [2009], Canary Islands region.

d Lončarić et al. [2006], southeast Atlantic.

e Bemis et al. [1998], culture.

${ }^{\mathrm{f}}$ King and Howard [2005], South Pacific.

${ }_{\mathrm{h}}$ Mortyn and Charles [2003], subpolar South Atlantic.

${ }^{\mathrm{h}}$ Bemis et al. [2000], culture.

${ }^{1}$ Sautter and Thunell [1991] and Simstich [1999].

${ }^{\mathrm{j}}$ Simstich et al. [2003], Nordic seas.

${ }_{1}^{\mathrm{k}}$ Reynolds and Thunell [1985].

${ }^{1}$ von Langen et al. [2000] as cited by Rohling et al. [2004], culture.

${ }^{\mathrm{m}}$ Ortiz et al. [1996], northeast Pacific.

${ }^{\mathrm{n}}$ Kohfeld et al. [2000], South Atlantic.

${ }^{\circ}$ Ganssen and Kroon [2000], Rohling et al. [2004], and Cléroux et al. [2007].

${ }^{\mathrm{p}}$ Wilke et al. [2006], southeast Atlantic.

${ }^{\mathrm{q}}$ Schiebel et al. [2002].

${ }^{\mathrm{r}}$ Mulitza et al. [1997] and Ganssen and Kroon [2000].

productivity values are based on the modern primary productivity (PP) data derived from Antoine et al. [1996]. PP was transferred into Pexp values following Eppley and Peterson [1979]. While the productivity transfer function underestimates Pexp in the high-productivity areas along the northwest African coast (annual Pexp $>250 \mathrm{gC} / \mathrm{m}^{2} * \mathrm{yr}$ ) good results are obtained for the Pexp range observed along the Portuguese margin at present [Salgueiro et al., 2009]. The large number of analog samples from the western Iberian margin (134) allows for paleotemperatures to be estimated on the basis of the 10 nearest neighbor $(\mathrm{NN})$ samples and paleoproductivity on $7 \mathrm{NN}$. Similarity values for SST and Pexp estimates exceed 0.7 in all samples, most often even 0.9. Pexp values shown in this paper are the mean for spring (April-June) and summer (July-September) and thus reflect the upwelling related productivity. SST and Pexp estimates presented here are distance-weighted values.
[14] The percentage of Neogloboquadrina pachyderma (s) is used as indicator for the presence of subpolar to polar surface waters on the Iberian margin. High percentages of this species coincide with abundance maxima of ice-rafted debris (IRD) [de Abreu et al., 2003; Eynaud et $a l ., 2009]$. The percentage sum of the deep dwelling planktonic foraminifera species Globorotalia crassaformis, Globorotalia hirsuta, G. inflata, Globorotalia scitula, and G. truncatulinoides (d) and (s) is here related to the nutrient and food availability in the subsurface waters and thus to water column stratification.

[15] In order to estimate the influence of the freshwater from Heinrich and other meltwater events on the water column along the Portuguese margin $\delta \mathrm{w}$ anomalies were calculated from the $\delta^{18} \mathrm{O}$ values of Globigerinoides ruber white, G. bulloides and N. pachyderma (d) and (s). We 
Table 5. Age Model for Core MD95-2040

\begin{tabular}{clcc}
\hline $\begin{array}{c}\text { Depth(s) } \\
(\mathrm{cm})\end{array}$ & \multicolumn{1}{c}{$\begin{array}{c}\text { Dated Material } \\
\text { (AMS Laboratory Code) }\end{array}$} & $\begin{array}{c}\text { Reservoir Corrected } \\
{ }^{14} \text { C Age } \pm \text { Error (yr BP) }\end{array}$ & $\begin{array}{c}\text { Calendar Age } \\
\text { (yr BP) }\end{array}$ \\
\hline 152.5 & G. bulloides (GIF98318) & $10,600 \pm 100$ & $12,620^{\mathrm{a}}$ \\
181.5 & End of Termination IA in GISP2 & & $14,640^{\mathrm{b}}$ \\
221.5 & N. pachyderma (KIA13457) & $13,130 \pm 80$ & $15,530^{\mathrm{a}}$ \\
239.5 & N. pachyderma (KIA13458) & $13,370 \pm 70$ & $15,880^{\mathrm{a}}$ \\
278.5 & N. pachyderma (KIA13460) & $14,050 \pm 90$ & $16,750^{\mathrm{a}}$ \\
281.5 & N. pachyderma (KIA13634) & $14,200 \pm 80$ & $16,950^{\mathrm{a}}$ \\
293.5 & SST tuned to GISP2 & & $17,429^{\mathrm{b}}$ \\
305.5 & SST tuned to GISP2 & & $17,741^{\mathrm{b}}$ \\
341.5 & SST tuned to GISP2 & & $19,240^{\mathrm{b}}$ \\
377.5 & SST tuned to GISP2 & $22,200 \pm 190$ & $20,300^{\mathrm{b}}$ \\
482.5 & Top DO interstadial 2 in GISP2 & & 23,420 \\
530.5 & SST tuned to GISP2 & & $24,363^{\mathrm{b}}$ \\
572.5 & N. pachyderma (GIF98322) & & $25,500^{\mathrm{c}}$ \\
575.5 & SST tuned to GISP2 & & $26,700^{\mathrm{b}}$ \\
608.5 & SST tuned to GISP2 & & $29,000^{\mathrm{b}}$ \\
647.5 & Top of Heinrich event 3 in GISP2 & $30,220^{\mathrm{b}}$ \\
728.5 & Base of Heinrich event 3 in GISP2 & & $31,520^{\mathrm{b}}$ \\
751.5 & Top DO Interstadial 5 in GISP2 & & \\
\hline
\end{tabular}

${ }^{\mathrm{a}}$ Calibrated with INTCAL04 [Reimer et al., 2004].

${ }^{\mathrm{b}}$ According to de Abreu et al. [2003].

${ }^{\mathrm{C}}$ Calibrated according to Hughen et al. [2004].

choose to show anomalies and not ice volume corrected values because the current sea level records do not resolve submillennial-scale changes linked to the Heinrich events. To calculate $\delta \mathrm{w}$ anomalies for $G$. ruber white and G. bulloides the summer SST (SSTsu) were used, while anomalies for $N$. pachyderma (d) were calculated with both summer and winter SST (SSTwi). As $N$. pachyderma (s) lives in colder waters only the winter SST were used for this species. Since G. bulloides and N. pachyderma (d/s) live deeper than $10 \mathrm{~m}$ water depth, -1 or $-2.5^{\circ} \mathrm{C}$, respectively, were subtracted from the SST values following Duplessy et al. [1991] and Weinelt et al. [1996]. Paleo- $\delta \mathrm{w}$ values were calculated based on the paleotemperature equations of Mulitza et al. [2003] with $\delta \mathrm{c}$, equaling $\delta^{18} \mathrm{O}_{\text {calcite, and } \delta \mathrm{w} \text { on }}$ the VPDB scale:

$$
\begin{aligned}
& \text { for G.ruber white }: \mathrm{T}=-4.44(\delta \mathrm{c}-\delta \mathrm{w})+14.20 \\
& \text { with } \mathrm{T}=\mathrm{SSTsu}\left({ }^{\circ} \mathrm{C}\right) \\
& \text { for G.bulloides }: \mathrm{T}=-4.70(\delta \mathrm{c}-\delta \mathrm{w})+14.62 \\
& \text { with } \mathrm{T}=\mathrm{SSTsu}-1\left({ }^{\circ} \mathrm{C}\right) \\
& \text { for } N . \text { pachyderma }(\mathrm{d}) \mathrm{T}=-3.55(\delta \mathrm{c}-\delta \mathrm{w}) \\
& +12.69 \text { with } \mathrm{T}=\mathrm{SSTsu}-2.5\left({ }^{\circ} \mathrm{C}\right) \\
& \text { or } \mathrm{T}=\mathrm{SSTwi}-1\left({ }^{\circ} \mathrm{C}\right) \\
& \text { for } N . \text { pachyderma }(\mathrm{s}) \mathrm{T}=-3.55(\delta \mathrm{c}-\delta \mathrm{w}) \\
& +12.69 \text { with } \mathrm{T}=\mathrm{SSTwi}-2.5\left({ }^{\circ} \mathrm{C}\right)
\end{aligned}
$$

For calculating $\delta \mathrm{w}$ the equation, for example for $G$. ruber white, would read:

$$
\delta \mathrm{w}=\delta \mathrm{c}-((\mathrm{T}-14.20) /-4.44)
$$

The $\delta \mathrm{w}$ anomaly was then calculated with:

$$
\delta^{18} \mathrm{O} \text { anomaly }=\delta \mathrm{w}-\left(0.9998 *\left(\delta \mathrm{w}_{\text {modern }}-0.27\right)\right)
$$

For the modern $\delta \mathrm{w}$ values at site MD99-2339 results from stations PO334-68, PO334-69 and PO334-72 were averaged for the respective depth interval and for sites MD95-2041 and MD95-2040 those from stations PO334-70 and PO334-71 (Table 2). Depth intervals were chosen based on the preferred calcification depth of the respective foraminifer (Table 4) resulting in the following average $\delta$ w values: for $G$. ruber white ( 0 to $50 \mathrm{~m}$ ) $0.94 \%$ for core MD99-2339 and $0.84 \%$ or cores MD95-2041 and MD95-2040; for $G$. bulloides (50 to $100 \mathrm{~m}$ ) $0.94 \%$ for core MD99-2339 and 0.82\% for cores MD95-2041 and MD95-2040; and for $N$. pachyderma (d) and (s) (100 to $250 \mathrm{~m})$ $0.86 \%$ for core MD99-2339 and $0.78 \%$ o for cores MD95-2041 and MD95-2040. $\delta \mathrm{w}$ values were converted from the SMOW scale to the VPDB scale by subtracting $0.27 \%$ [Hut, 1987].

[16] All paleodata will be publicly available through the World Data Centre Mare (http://www. wdc-mare.org; http://www.pangaea.de).

\section{Stratigraphy}

[17] The focus of this study is the similarities and discrepancies between the four sites and what they indicate for the Iberian margin hydrography. The 
Table 6. Age Model for Core MD95-2041

\begin{tabular}{|c|c|c|c|c|c|}
\hline $\begin{array}{l}\operatorname{Depth}(\mathrm{s}) \\
\quad(\mathrm{cm})\end{array}$ & Dated Material & $\begin{array}{l}\text { AMS Laboratory } \\
\text { Code }\end{array}$ & $\begin{array}{l}\text { Sample Weight } \\
(\mathrm{mg})\end{array}$ & $\begin{array}{c}\text { Reservoir Corrected } \\
{ }^{14} \mathrm{C} \text { Age } \pm \text { Error } \\
\text { (yr BP) }\end{array}$ & $\begin{array}{l}\text { Calendar Age } \\
\text { (yr BP) }\end{array}$ \\
\hline 171.5 & Base of Bølling in GISP2 & & & & 14,500 \\
\hline 321.5 & G. inflata $>250 \mu \mathrm{m}$ & OS-42903 & 6.8 & $16,400 \pm 95$ & $19,565^{\mathrm{a}}$ \\
\hline 401.5 & $\begin{array}{l}\text { G. bulloides, G. calida, } \\
\text { G. ruber, } O \text {. universa }>250 \mu \mathrm{m}\end{array}$ & OS-42904 & 14.7 & $18,700 \pm 95$ & $22,270^{\mathrm{a}}$ \\
\hline 561.5 & G. inflata $>250 \mu \mathrm{m}$ & OS-42905 & 10.6 & $23,700 \pm 100$ & $27,200^{\mathrm{b}}$ \\
\hline 601.5 & G. inflata $>250 \mu \mathrm{m}$ & OS-42906 & 12.8 & $24,700 \pm 110$ & $28,570^{\mathrm{b}}$ \\
\hline 616.5 & Top of Heinrich event 3 in GISP2 & & & & 29,000 \\
\hline 641.5 & Base of Heinrich event 3 in GISP2 & & & & 30,220 \\
\hline
\end{tabular}

relationships to the Greenland ice core records were discussed in previous contributions. Because two of the core sites included in this study have published stratigraphies linked to the GISP2 ice core [de Abreu et al., 2003; Voelker et al., 2006], we decided to keep correlations to the GISP2 stratigraphy in tact and not to convert age models to the GICC05 [Andersen et al., 2006] or SFCP04 [Shackleton et al., 2004] time scales. Consequently, we are also using the GISP2 linked ${ }^{14} \mathrm{C}$ "calibration" data sets [Voelker et al., 1998; Hughen et al.,
2004] to convert reservoir-corrected ${ }^{14} \mathrm{C}$ ages beyond the INTCAL04 range into calendar ages (Tables 5-8). Therefore the age scales of the paleorecords are consistent between each other, but absolute age ranges for selected events and GS might vary in relation to other ice core or speleothem chronologies. We decided to use a reservoir correction of 400 years for all the records and all ${ }^{14} \mathrm{C}$ ages but are aware that reservoir ages might have been significantly higher during Heinrich events [Sarnthein et al., 2001; Waelbroeck et al., 2001],

Table 7. Age Model for Core MD99-2336 ${ }^{\mathrm{a}}$

\begin{tabular}{|c|c|c|c|c|c|}
\hline $\begin{array}{l}\text { Depth(s) } \\
\text { (cm) }\end{array}$ & Dated Material & $\begin{array}{l}\text { AMS Laboratory } \\
\text { Code }\end{array}$ & $\begin{array}{l}\text { Sample Weight } \\
(\mathrm{mg})\end{array}$ & $\begin{array}{l}\text { Reservoir Corrected } \\
{ }^{14} \mathrm{C} \text { Age } \pm \text { Error } \\
\text { (yr BP) }\end{array}$ & $\begin{array}{l}\text { Calendar Age } \\
\text { (yr BP) }\end{array}$ \\
\hline 23 & G. ruber white+pink & OS-42751 & 6.9 & $2060 \pm 30$ & $2030^{b}$ \\
\hline 63 & G. ruber white+ pink & OS-42752 & 9.4 & $4770 \pm 30$ & $5520^{\mathrm{b}}$ \\
\hline 77 & G. inflata $>250 \mu \mathrm{m}$ & KIA 23662 & 24.5 & $3420 \pm 40$ & $3670^{b}$ \\
\hline 101 & G. inflata $>250 \mu \mathrm{m}$ & OS-42753 & 11.4 & $4510 \pm 25$ & $5160^{\mathrm{b}}$ \\
\hline 200 & $\begin{array}{l}\text { correlation with MD95-2042 } \\
\text { on GISP2 chronology }\end{array}$ & & & & $\mathbf{9 5 3 3}^{\mathrm{c}}$ \\
\hline 235 & $\begin{array}{l}\text { correlation with MD95-2042 } \\
\text { on GISP2 chronology }\end{array}$ & & & & $10,677^{c}$ \\
\hline 267 & G. inflata $>250 \mu \mathrm{m}$ & OS-42754 & 13.2 & $11,100 \pm 40$ & $13,010^{\mathrm{b}}$ \\
\hline 291 & G. bulloides $>250 \mu \mathrm{m}$ & OS-42755 & 10.2 & $13,600 \pm 50$ & $16,190^{\mathrm{b}}$ \\
\hline 330 & $\begin{array}{l}\text { correlation with MD95-2042 } \\
\text { on GISP2 chronology }\end{array}$ & & & & $18,037^{\mathrm{c}}$ \\
\hline $\begin{array}{l}347-348.75 \\
655\end{array}$ & $\begin{array}{l}\text { G. inflata }>250 \mu \mathrm{m} \\
\text { correlation with MD95-2042 } \\
\quad \text { on GISP2 chronology }\end{array}$ & OS-42902 & 7.9 & $14,500 \pm 75$ & $\begin{array}{l}17,460^{\mathrm{b}} \\
\mathbf{2 3 , 9 1 5}\end{array}$ \\
\hline 722 & $\begin{array}{l}\text { G. bulloides, G. calida, } \\
\text { O. univers }>250 \mu \mathrm{m}\end{array}$ & KIA 23842 & 4.2 & $21,820 \pm 140$ & $25,170^{\mathrm{d}}$ \\
\hline 730 & $\begin{array}{l}\text { correlation with MD95-2042 } \\
\text { on GISP2 chronology }\end{array}$ & & & & $25,660^{c}$ \\
\hline 806 & G. bulloides, G. calida & KIA 23843 & 4.5 & $25,530+200 /-190$ & $29,330^{\mathrm{d}}$ \\
\hline 815 & $\begin{array}{l}\text { correlation with MD95-2042 } \\
\text { on GISP2 chronology }\end{array}$ & & & & $35,749^{c}$ \\
\hline
\end{tabular}


Table 8. Age Model for core MD99-2339

\begin{tabular}{|c|c|c|c|c|c|}
\hline $\begin{array}{l}\operatorname{Depth}(\mathrm{s}) \\
(\mathrm{cm})\end{array}$ & Dated Material & $\begin{array}{l}\text { AMS Laboratory } \\
\text { Code }\end{array}$ & $\begin{array}{l}\text { Sample Weight } \\
\text { (mg) }\end{array}$ & $\begin{array}{l}\text { Reservoir Corrected } \\
{ }^{14} \mathrm{C} \text { Age } \pm \text { Error } \\
\text { (yr BP) }\end{array}$ & $\begin{array}{c}\text { Calendar Age } \\
\text { (yr BP) }\end{array}$ \\
\hline 217.5 & surface dwelling foram. & OS-37238 & 5.6 & $10,350 \pm 65$ & $12,259^{\mathrm{a}}$ \\
\hline 277.5 & deep dwelling foram. & OS-37239 & 6.9 & $12,250 \pm 55$ & $14,375^{\mathrm{a}}$ \\
\hline 433.5 & Pteropod fragments & OS-37240 & 21.3 & $15,950 \pm 85$ & $19,039^{\mathrm{a}}$ \\
\hline 633.5 & $\begin{array}{l}\% \text { N. pachyderma (s) maximum } \\
\text { within H2 IRD interval } \\
\text { tuned to GISP2 }\end{array}$ & & & & 23,800 \\
\hline 813.5 & deep dwelling foram. & OS-37241 & 4.3 & $25,000 \pm 180$ & $28,700^{\mathrm{b}}$ \\
\hline 956.5 & surface dwelling foram. & OS-37242 & 3.5 & $28,600 \pm 170$ & $33,100^{\mathrm{b}}$ \\
\hline
\end{tabular}

${ }^{a}$ Calibrated with INTCAL04 [Reimer et al., 2004].

${ }^{\mathrm{b}}$ Calibrated according to Voelker et al. [1998].

especially at site MD95-2040. The three more southern cores, on the other hand, are from the same latitude or south of site MD95-2042, for which Bard et al. [2004] also assumed a typical 400 year correction to be dominant during the glacial period. For the stratigraphic subdivision within MIS 2, we are following the INTIMATE group's [Lowe et al., 2008] nomenclature of GS and Greenland interstadials, here applied to the GISP2 $\delta^{18} \mathrm{O}$ record. With this subdivision the LGM is part of GS 2 b (e.g., Figure 8). Positions and age ranges of Heinrich events within the respective GS follow Rousseau et al. [2006] and Bard et al. [2000], respectively. For the lower boundary of Heinrich event 1 , however, we are using the lower boundary of GS 2a (17.8 cal ka in GISP2), which makes this boundary slightly younger than the one given by Bard et al. [2000] (18 cal $\mathrm{ka}$ ), but older than the one given by Bond et al. [1999] for this event in the Heinrich IRD belt (17.5 cal ka).

[18] Following the strategy outlined above, the chronostratigraphy for core MD95-2040 (Table 5) is mainly based on the one of de Abreu et al. [2003]. However, the ${ }^{14} \mathrm{C}$ ages used in the age model by de Abreu et al. [2003] were calibrated anew with the INTCAL04 data set [Reimer et al., 2004]. The recalibration led to age reversals for the ${ }^{14} \mathrm{C}$ ages at $290.5 \mathrm{~cm}, 488.5 \mathrm{~cm}$ and $512.5 \mathrm{~cm}$ in regard to the surrounding GISP2 tuned ages, so that they were omitted in the revised age model. These age reversals result most likely from underestimating the respective reservoir age. A tuning point to the GISP2 chronology [Meese et al., 1994] was added at $482.5 \mathrm{~cm}$ (Table 5 and Figure 3). For core MD95-2041, 4 AMS ${ }^{14} \mathrm{C}$ were obtained (Table 6 and Figure 4). At the top and bottom of the studied interval the calibrated ${ }^{14} \mathrm{C}$ ages are supported by three tuning points to the GISP2 $\delta^{18} \mathrm{O}$ record. The age model of core MD99-2339 follows Voelker et al. [2006] and has four control points within the studied interval (Figure 6) which are derived from three calibrated AMS ${ }^{14} \mathrm{C}$ dates and one tuning point to the GISP2 $\delta^{18} \mathrm{O}$ record. The tuning point aligns the $\% N$. pachyderma (s) maximum within the Heinrich event 2 related IRD peak to the $\delta^{18} \mathrm{O}$ minimum preceding Greenland interstadial 2 in the GISP2 $\delta^{18} \mathrm{O}$ record based on the assumption that this coldest interval in the Gulf of Cadiz should coincide with a period of maximum sea ice extension in the North Atlantic.

[19] The age model of core MD99-2336 based solely on the calibrated ${ }^{14} \mathrm{C}$ ages (Table 7) resulted in extreme changes in the sedimentation rates. As some of the dates were obtained within a contouritic layer they could be affected by older foraminifera shells advected with the Mediterranean Outflow Water. Furthermore, the drift sediments in the Gulf of Cadiz are sometimes highly bioturbated as revealed by ichnofossils and their affect on ${ }^{14} \mathrm{C}$ dates [Löwemark and Werner, 2001; Löwemark et al., 2004]. So a different approach was used in the glacial section of the core by correlating its G. bulloides $\delta^{18} \mathrm{O}$ record with the one of core MD95-2042 on its GISP2 tuned chronology [Shackleton et al., 2000]. The resulting chronology fits well with the one established based on magnetic data $(\mathrm{N}$. Thouveny, unpublished data, 2005). Surprisingly, the calibrated ${ }^{14} \mathrm{C}$ ages at 267 and $722 \mathrm{~cm}$ agree within their error with the tuned ages at their respective depths. The depths used as age control points are highlighted in bold in Table 7.

[20] Figure 7 shows the resulting age-depth profiles and sedimentation rates for the four cores. In core MD99-2336, the sedimentation rate increased significantly during GS 2 due to sediment supply by the upper MOW core [Llave et al., 2006]. Core MD95-2040 is also experiencing some abrupt 


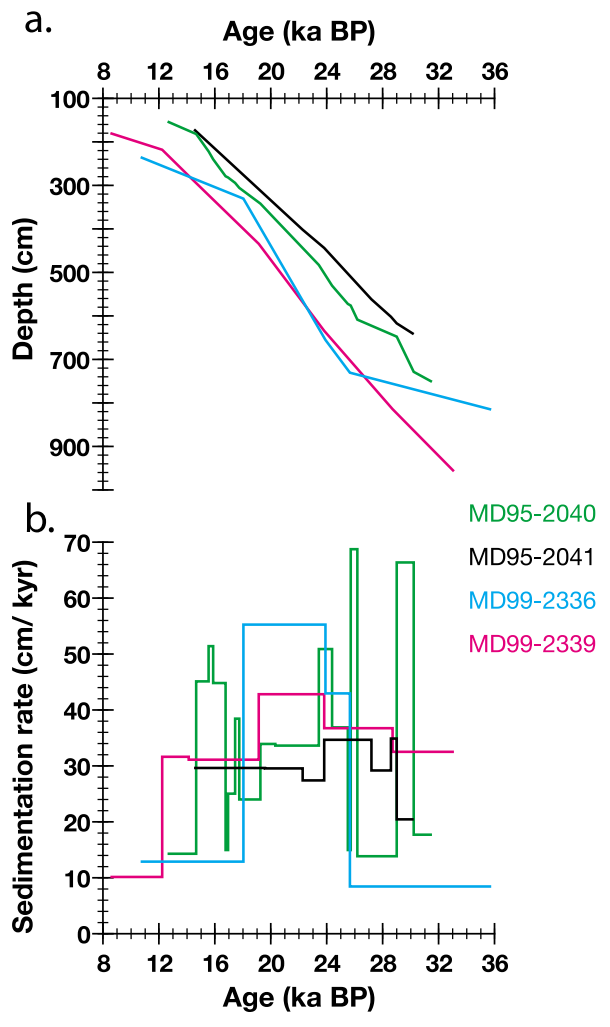

Figure 7. (a) Age-depth profiles for the studied cores and (b) the sedimentation rates resulting from the chosen age control points.

changes in the sedimentation rate (Figure $7 b$ ) but some of these might be artifacts due to the mixture of calibrated ${ }^{14} \mathrm{C}$ ages and GISP2 ages. Overall the age-depth profiles of cores MD95-2040, MD952041 and MD99-2339 show parallel trends during MIS 2 (Figure 7a).

\section{Results}

\subsection{Core MD95-2040}

[21] Stable isotope ratios were measured from six foraminiferal species (Figure 3). G. ruber white specimens were, however, only available for the late phase of GS $2 a$ and the interval from Greenland interstadial 2 to the end of the LGM (Figure 8). $N$. pachyderma (s), on the other hand, was sparse during GS 2c, Greenland interstadial 3 and the early part of GS 3 . When $G$. ruber white was present its $\delta^{18} \mathrm{O}$ values were the lightest followed by G. bulloides and/or N. pachyderma (r). Outside of meltwater events, $G$. inflata and G. scitula values were generally the heaviest. In early MIS 2 and during late GS 2a, $N$. pachyderma (s) values were usually also heavy and in the range of
G. scitula (Figure 3). During the LGM, values were lighter than those of the subsurface dwellers. Outside of the LGM, G. truncatulinoides (r) $\delta^{18} \mathrm{O}$ values show extreme oscillations and were unusually light for such a deep dwelling species. $\delta^{13} \mathrm{C}$ values of $G$. truncatulinoides $(r)$ were the heaviest followed by $G$. inflata and $G$. ruber white that generally had similar values (Figures 3 and 8f). N. pachyderma (r), N. pachyderma (s), G. scitula, and G. bulloides had negative values. While present, $\delta^{13} \mathrm{C}$ variations were relatively small for each species. Only G. truncatulinoides (r) and G. inflata showed some larger-scale variations in the early part of MIS 2. G. bulloides [Bemis et al., 2000] and G. scitula [Ortiz et al., 1996; Itou et al., 2001] deviated more strongly and thus exhibited the lightest $\delta^{13} \mathrm{C}$ values due to their vital effects (Table 4).

[22] At this northernmost site, which is located within in the southern latitudes of the North Atlantic IRD belt [Ruddiman, 1977; Hemming, 2004], percentages of $N$. pachyderma (s) increased significantly during Heinrich events contributing more than $60 \%$ to the fauna (Figure $8 \mathrm{~g}$ ). With the increase of $N$. pachyderma (s) the amount of deep dwelling foraminifer decreased. Overall, deep dwelling foraminifers were more common during the warmer intervals of MIS 2 and the LGM when they made up nearly a third of the total fauna. SSTsu ranged from 5.0 to $18.9^{\circ} \mathrm{C}$ and SSTwi from 1.0 to $14.9^{\circ} \mathrm{C}$ with the coldest SST occurring during the Heinrich events, especially Heinrich event 1 (Figure 8h). Pexp values estimated for the upwelling season varied between 129 and $249 \mathrm{gC} / \mathrm{m}^{2} * \mathrm{yr}$ (Figure 11).

\subsection{Core MD95-2041}

[23] In addition to the six species analyzed for core MD95-2040, also one G. truncatulinoides (s) data point exists (Figure 4). N. pachyderma (s) specimens were less abundant, so that this species was mainly measured during the Heinrich events and GS 4 (Figures 4 and 9). G. ruber white and $G$. truncatulinoides (r), on the other hand, were scarce during GS 2a/Heinrich event 1 and could be analyzed at only one level during this interval. For most of MIS 2 prior to Heinrich event 1, G. ruber white $\delta^{18} \mathrm{O}$ were the lightest followed by G. bulloides and $N$. pachyderma (r) whose values often merge. $N$. pachyderma (s) values are mostly heavier than those of $N$. pachyderma (r) and at levels similar to $G$. bulloides during the cold phases. G. scitula was either at a range equal to $G$. inflata or lighter, while G. truncatulinoides (r) generally reveals the heavi- 


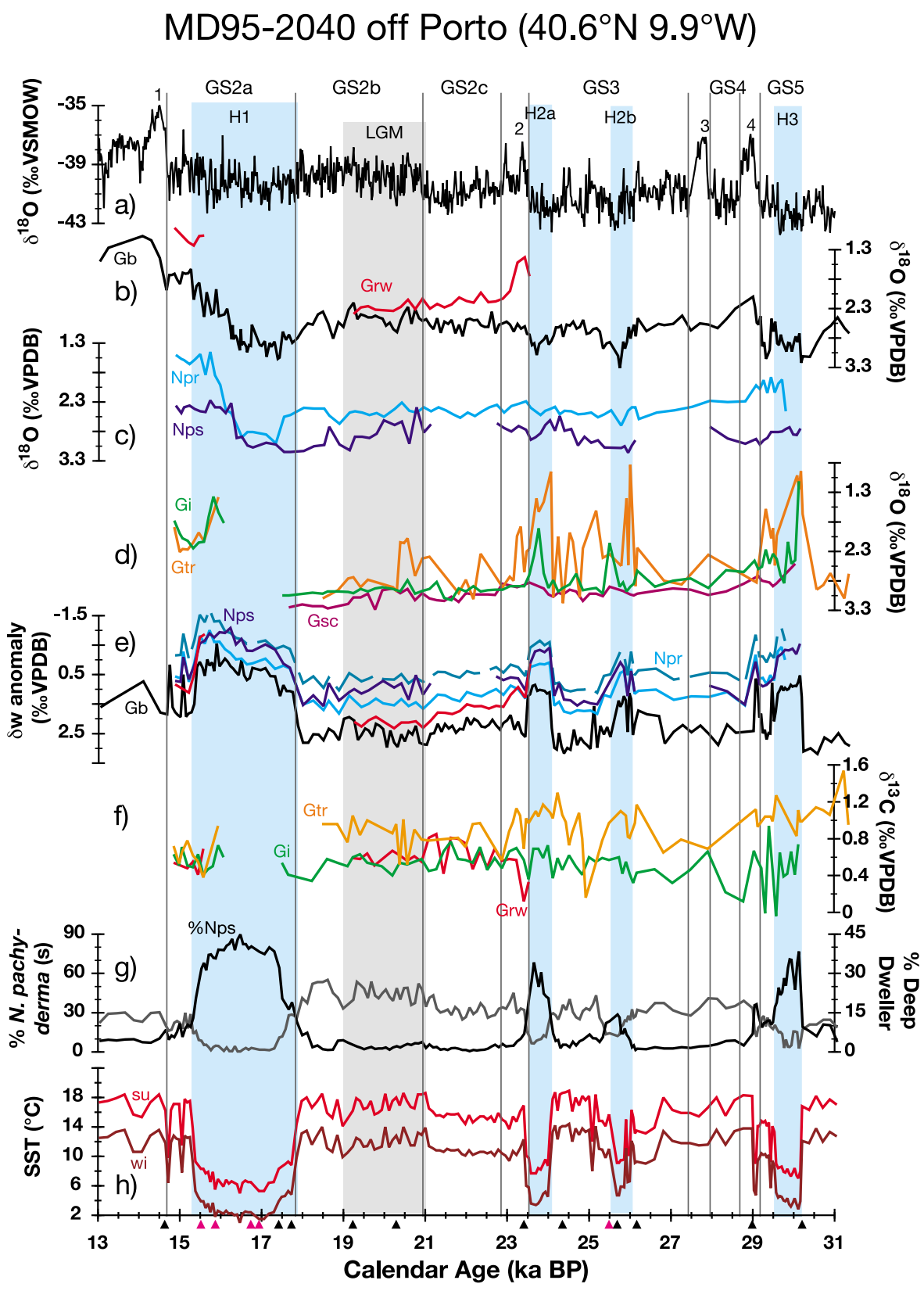

Figure 8. (a) The GISP2 $\delta^{18} \mathrm{O}$ record in comparison to (b-h) climate records of core MD95-2040 [Stuiver and Grootes, 2000]. Figure 8b shows G. ruber white (Grw; red) and G. bulloides (Gb; black) $\delta^{18} \mathrm{O}$ records; Figure 8c shows $N$. pachyderma (r) (Npr; light blue) and $N$. pachyderma (s) (Nps; dark blue) $\delta^{18} \mathrm{O}$ records; Figure 8d shows G. inflata (Gi; green), G. scitula (Gsc; purple), and G. truncatulinoides (r) (Gtr; orange) $\delta^{18} \mathrm{O}$ records; Figure 8e shows $\delta \mathrm{w}$ anomalies estimated from the respective foraminifer $\delta^{18} \mathrm{O}$ and SST values. Data based on G. ruber white are in red, data based on G. bulloides are in black, data based on N. pachyderma (r) are in light blue (with summer $\mathrm{SST}$ ) or as dashed line (winter SST), and data based on $N$. pachyderma (s) are in dark blue. Figure $8 \mathrm{f}$ shows $\delta^{13} \mathrm{C}$ records of G. ruber white, G. inflata, and G. truncatulinoides (r). Figure 8g shows percentages of N. pachyderma (s) (black) and of deep dwelling foraminifer (gray) in the planktonic foraminifer fauna. Figure $8 \mathrm{~h}$ shows estimated summer (su; light red) and winter (wi; dark red) SST. Blue bars indicate Heinrich $(\mathrm{H})$ events, and gray bar indicates the LGM. Boundaries and nomenclature of GS and interstadials according to Lowe et al. [2008]. Black (tuned) and magenta $\left({ }^{14} \mathrm{C}\right.$ based) triangles mark the respective age control points. 
MD95-2041 off Sines $\left(37.8^{\circ} \mathrm{N} 9.5^{\circ} \mathrm{W}\right)$

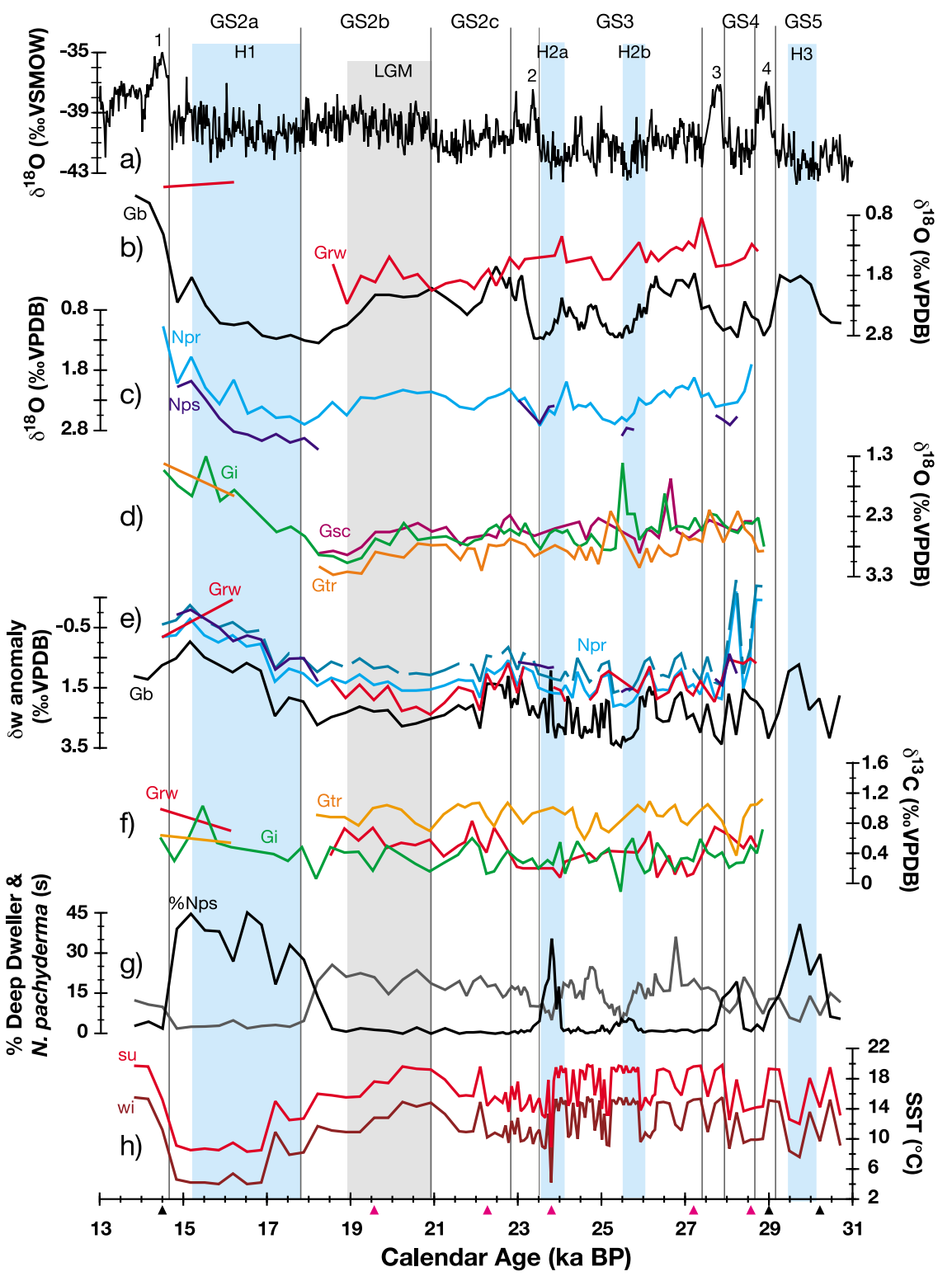

Figure 9. (a) The GISP2 $\delta^{18} \mathrm{O}$ record in comparison to $(\mathrm{b}-\mathrm{h})$ climate records of core MD95-2041 [Stuiver and Grootes, 2000]. Figure 9b shows G. ruber white (red) and G. bulloides (black) $\delta^{18} \mathrm{O}$ records; Figure $9 \mathrm{c}$ shows $N$. pachyderma (r) (light blue) and N. pachyderma (s) (dark blue) $\delta^{18} \mathrm{O}$ records; Figure $9 \mathrm{~d}$ shows G. inflata (green), G. scitula (purple), and G. truncatulinoides (r) (orange) $\delta^{18} \mathrm{O}$ records; and Figure 9e shows $\delta \mathrm{w}$ anomalies estimated from the respective foraminifer $\delta^{18} \mathrm{O}$ and SST values. Data based on $G$. ruber white are in red, data based on G. bulloides are in black, data based on N. pachyderma (r) are in light blue (with summer SST) or as dashed line (winter SST), and data based on $N$. pachyderma (s) are in dark blue. Figure $9 \mathrm{f}$ shows $\delta^{13} \mathrm{C}$ records of $G$. ruber white, G. inflata, and G. truncatulinoides. Figure $9 \mathrm{~g}$ shows percentages of $N$. pachyderma (s) (black) and of deep dwelling foraminifer (gray). Note the same scale for both. Figure 9h estimated summer (light red) and winter (dark red) SST. Bars and stratigraphic information are the same as in Figure 8. Black (tuned) and magenta $\left({ }^{14} \mathrm{C}\right.$ based) triangles mark the respective age control points.

est values. For $\delta^{13} \mathrm{C}$, G. truncatulinoides (r) showed the heaviest values followed by $G$. inflata and $G$. ruber white whose values were quite similar (Figures 4 and 9f). N. pachyderma (d/s) and
G. scitula also had a similar $\delta^{13} \mathrm{C}$ range, while for most of the record G. bulloides showed the lightest values. Variability in these four latter species was larger than at site MD95-2040. 
[24] At this site, percentages of $N$. pachyderma (s) reached maximum values between 35 and $45 \%$ during Heinrich events 1, 2a and 3 and were below $5 \%$ during Greenland interstadial 3 and the following interval up to $\mathrm{H} 2 \mathrm{~b}$ and during the LGM (Figure 9g). Different from site MD95-2040 there is a clear increase in \% $N$. pachyderma (s) also during GS 4. The deep dweller fauna nearly disappeared during Heinrich event 1, but was present in small numbers during the preceding Heinrich events and GS 4. Similar to core MD95-2040 deep dwellers contributed up to a third to the planktonic foraminifer fauna. SSTsu varied between 8.3 and $19.9^{\circ} \mathrm{C}$ and SSTwi between 4.0 and $15.6^{\circ} \mathrm{C}$ (Figure 9h). Upwelling related export productivity ranged from 137 to $245 \mathrm{gC} / \mathrm{m}^{2} * \mathrm{yr}$ (Figure 11).

\subsection{Core MD99-2336}

[25] Three foraminifer species were analyzed in this core. G. ruber white and G. bulloides as surface dwellers and $G$. truncatulinoides (r) as deep dweller (Figure 5). During the LGM, G. ruber white and $G$. bulloides showed similar $\delta^{18} \mathrm{O}$ values, but they diverged with $G$. bulloides revealing heavier values during Heinrich event 1 and the Boelling. During GS 2b, G. truncatulinoides (r) $\delta^{18} \mathrm{O}$ values were around $1 \%$ heavier than the ones of the surface dwellers, but they merged with the G. bulloides data at the onset of Heinrich event 1 . The few data points during Heinrich event 1 showed values lighter than $G$. bulloides, while during the Boelling they were lighter than during GS 2 b but slightly heavier than the G. bulloides data. In $\delta^{13} \mathrm{C}$ G. ruber white and G. truncatulinoides (r) exhibited relative stable records that in contrast to the other records only had a minor offset.

\subsection{Core MD99-2339}

[26] G. ruber white $\delta^{18} \mathrm{O}$ values were generally the lightest, but they merged with $G$. bulloides during GS $2 \mathrm{c}$ and $\mathrm{b}$ (Figures 6 and 10). Also in some of the warmer oscillations during early MIS 2, G. ruber white and G. bulloides values were close. Although mostly heavier, $N$. pachyderma $(\mathrm{r}) \delta^{18} \mathrm{O}$ levels were not much different from those of $G$. bulloides and the shape of both records was similar. G. inflata and G. truncatulinoides (r) exhibited the heaviest values with $G$. inflata being slightly lighter. Except for a few short oscillations during GS $2 \mathrm{c}$ and $2 \mathrm{~b}$, the G. truncatulinoides (r) $\delta^{18} \mathrm{O}$ record was relatively smooth. For $G$. inflata such stability was only seen during GS $2 \mathrm{c}$ and $2 \mathrm{~b}$. The few points analyzed for G. scitula indicated levels similar to those of $G$. inflata. Similar to the other sites, $G$. truncatulinoides ( $r$ ) revealed the heaviest $\delta^{13} \mathrm{C}$ values and $G$. ruber white and $G$. inflata values were similar (Figures 6 and 10f). $N$. pachyderma $(\mathrm{r}) \delta^{13} \mathrm{C}$ varies by more than $0.5 \%$ and was mainly heavier than G. bulloides, which also experienced strong variations. The few $G$. scitula data points were generally closer to the $N$. pachyderma (r) than G. bulloides values.

[27] Percentages of N. pachyderma (s) were quite low in the central Gulf of Cadiz with maximum values reaching 9.5\% during Heinrich event 1 (Figure $10 \mathrm{~g}$ ). A small increase was also observed during Heinrich event 3, while percentages during the other cold phases hardly exceeded the MIS 2 background level. With the exception of the Heinrich events, a third of the fauna consisted of deep dwelling foraminifer until $17.5 \mathrm{cal} \mathrm{ka}$. During the Boelling, the deep dwellers became more abundant and contributed up to $55 \%$ to the fauna. SSTsu varied between 9.9 and $22.7^{\circ} \mathrm{C}$ and SSTwi between 6.3 and $17.7^{\circ} \mathrm{C}$ (Figure 10h). Pexp ranged from 60 to $280 \mathrm{gC} / \mathrm{m}^{2} * \mathrm{yr}$ (Figure 11).

\section{Hydrography and Productivity Changes During MIS 2}

[28] The faunal SST reconstructed with the regionally extended modern analog database agreed well with the mean annual temperatures estimated from alkenone concentrations for core MD95-2040 [Pailler and Bard, 2002] and for cores SU81-18 and MD95-2042 near to site MD95-2041 [Bard et al., 2000; Pailler and Bard, 2002] thus showing that the faunal based temperatures were reliable. With the exception of the Heinrich events (see section 6.3), sufficient nutrients and food were available in the subsurface waters to sustain a healthy deep dwelling foraminifer fauna (Figures $8 \mathrm{~g}$, $9 \mathrm{~g}$, and $10 \mathrm{~g}$ ), thus no major stratification hindered fluxes from the surface mixed layer to the deeper layers during most of MIS 2.

\subsection{Conditions During Early MIS 2}

[29] The interval between Greenland Interstadial 3 and the top of Heinrich event 2a marks GS 3 [Lowe et al., 2008]. Because Heinrich events are discussed separately (see section 6.3) we focus here on the sections of GS 3 excluding Heinrich events $2 \mathrm{a}$ and $2 \mathrm{~b}$. G. ruber white was hardly present during this interval in core MD95-2040 [de Abreu et al., 2003] and poleward heat transport was lower than during the LGM (see section 6.2) and GS $2 \mathrm{c}$. 
MD99-2339, Gulf of Cadiz $\left(35.9^{\circ} \mathrm{N} 7.5^{\circ} \mathrm{W}\right)$

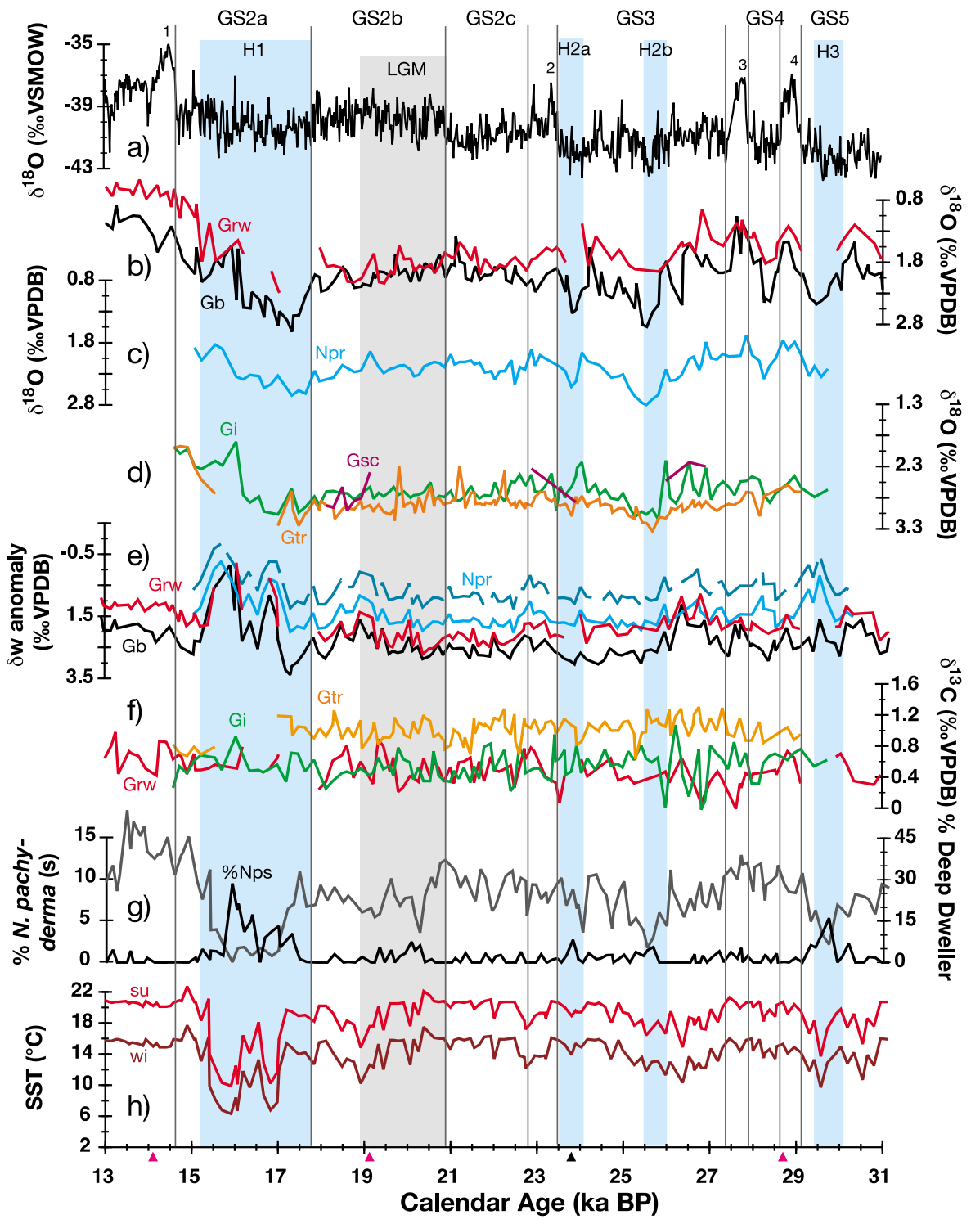

Figure 10. (a) The GISP $2 \delta^{18} \mathrm{O}$ record in comparison to $(\mathrm{b}-\mathrm{h})$ climate records of core MD95-2339 [Stuiver and Grootes, 2000]. Figure 10b shows G. ruber white (Grw; red) and G. bulloides (Gb; black) $\delta^{18} \mathrm{O}$ records; Figure $10 \mathrm{c}$ shows N. pachyderma (r) (Npr) $\delta^{18} \mathrm{O}$ record; Figure 10d shows G. inflata (Gi; green), G. scitula (Gsc; purple), and G. truncatulinoides (r) (Gtr; orange) $\delta^{18} \mathrm{O}$ records; Figure 10e shows $\delta \mathrm{w}$ anomalies estimated from the respective foraminifer $\delta^{18} \mathrm{O}$ and SST values. Data based on G. ruber white are in red, data based on G. bulloides are in black, and data based on N. pachyderma (r) are in light blue (with summer SST) or as dashed line (winter SST). Figure 10f shows $\delta^{13} \mathrm{C}$ records of $G$. ruber white, G. inflata, and G. truncatulinoides. Figure $10 \mathrm{~g}$ shows percentages of $N$. pachyderma (s) (black) and of deep dwelling foraminifer (gray). Figure 10h shows estimated summer (light red) and winter (dark red) SST. Bars and stratigraphic information are the same as in Figure 8. Black (tuned) and magenta $\left({ }^{14} \mathrm{C}\right.$ based) triangles mark the respective age control points.

Conditions during GS 3 were unstable as evidenced by frequent oscillations in SST (Figures $9 \mathrm{~h}$ and $10 \mathrm{~h}$ ) and $\delta \mathrm{w}$ (Figures 9e and 10e). In comparison to GS $2 \mathrm{c}$ and $2 \mathrm{~b}$ there was also more variability in the properties of the deep winter mixed layer and the subthermocline waters (Figures 8c, 8d, 8f, 9c, 9d, 9f, 10c, 10d, and 10f). The seasonal temperature gradient based on the $\delta^{18} \mathrm{O}$ difference between G. inflata (winter mixed layer) and G. bulloides (late spring to summer mixed layer) [Ganssen and Kroon, 2000] also differed (Figure 12a). In comparison to the LGM, the seasonality in the Gulf of 


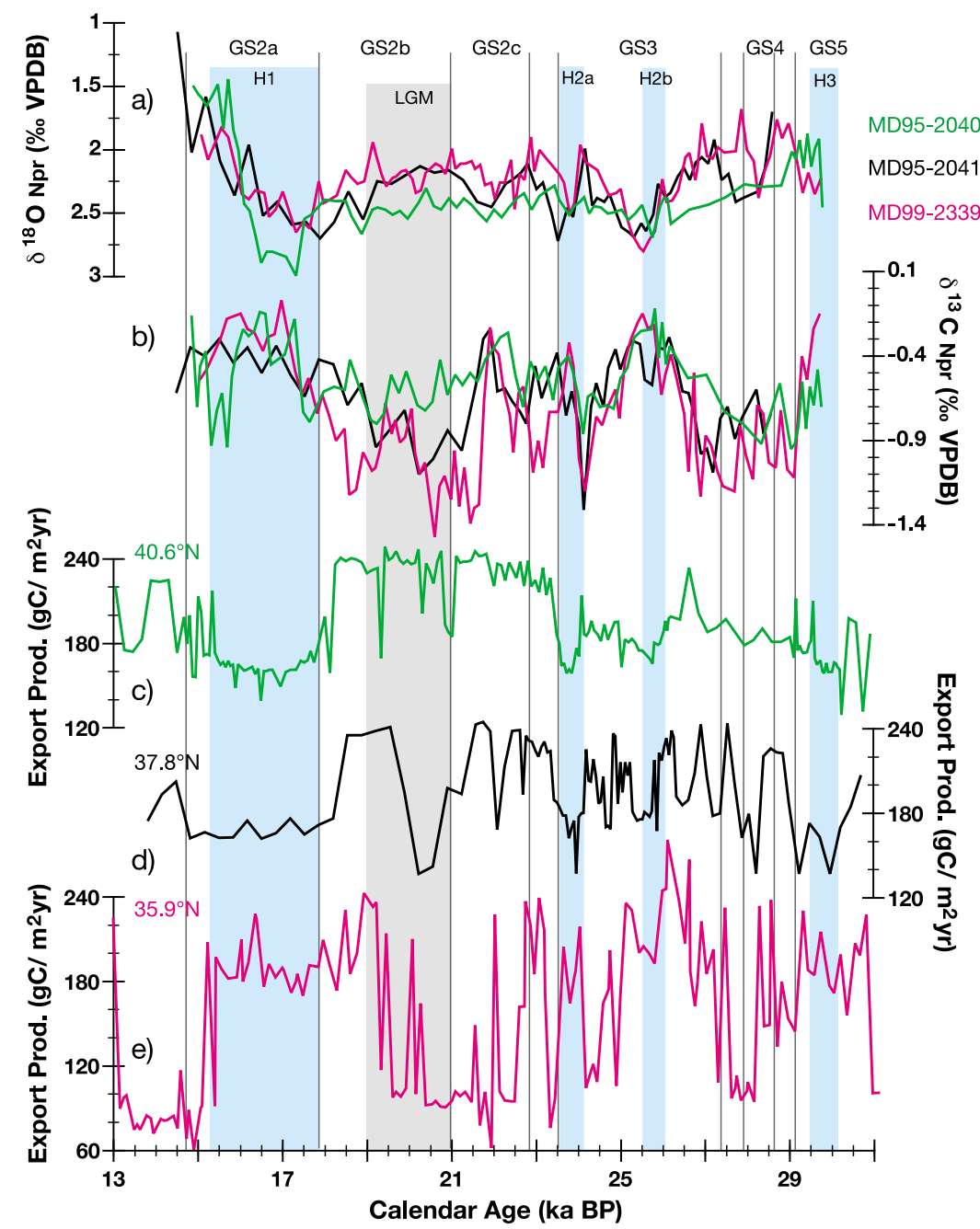

Figure 11. N. pachyderma (r) (a) $\delta^{18} \mathrm{O}$ and (b) $\delta^{13} \mathrm{C}$ records of core MD95-2040 (green), MD95-2041 (black), and MD99-2339 (magenta) and (c-e) export productivity estimated for each core. Note that scaling, but not length of scale, in Figures 11c-11e is the same for the three export productivity plots. Latitude of respective core site is listed above the export productivity record. Bars and stratigraphic information are the same as in Figure 8.

Cadiz (MD99-2339) was larger during early GS 3 but reduced during the interval between Heinrich events $2 \mathrm{~b}$ and $2 \mathrm{a}$. Lower seasonal gradients were also observed on the western margin at sites MD95-2040 and MD95-2041 (Figure 12a). The dissimilarity in climate conditions between early GS 3 and GS 2c and 2b was further supported by a larger surface to deep subsurface temperature gradient (Figures 12b and 12c). Some of this increased temperature variability was probably linked to the upwelling. The export productivity record of core MD95-2041 (Figure 11d) clearly showed that upwelling strength in the Sines area varied between strong and reduced and this would directly impact $G$. bulloides as the upwelling-related foraminifer species [Salgueiro et al., 2008]. Site MD95-2041 is located closer to the coast than site MD95-2042 and thus was probably stronger influenced by the filament forming off Cape Sines (Figure 1c). In addition, planktonic foraminifers are feeding on diatoms [Hemleben et al., 1989], which thrive better than coccolithophorids in upwelled waters [Legrende and le Fevre, 1989]. This could explain why Pailler and Bard's [2002] accumulation rate of total biomarkers, which are produced by coccolithophorids, indicates lower productivity for early MIS 2 in core MD95-2042. On the other hand, coccolithophorid productivity was increased during this period at site MD95-2040 [Pailler and Bard, 2002]. Turbulence and thus upwelling was reduced in agreement with the lower export productivity we observed at this site for the overall upwelling season (Figure 11c). The shift from an upwelling regime to a situation that was more similar to a spring bloom with coccolithophorids as primary producers could explain why the planktonic $\delta^{13} \mathrm{C}$ 


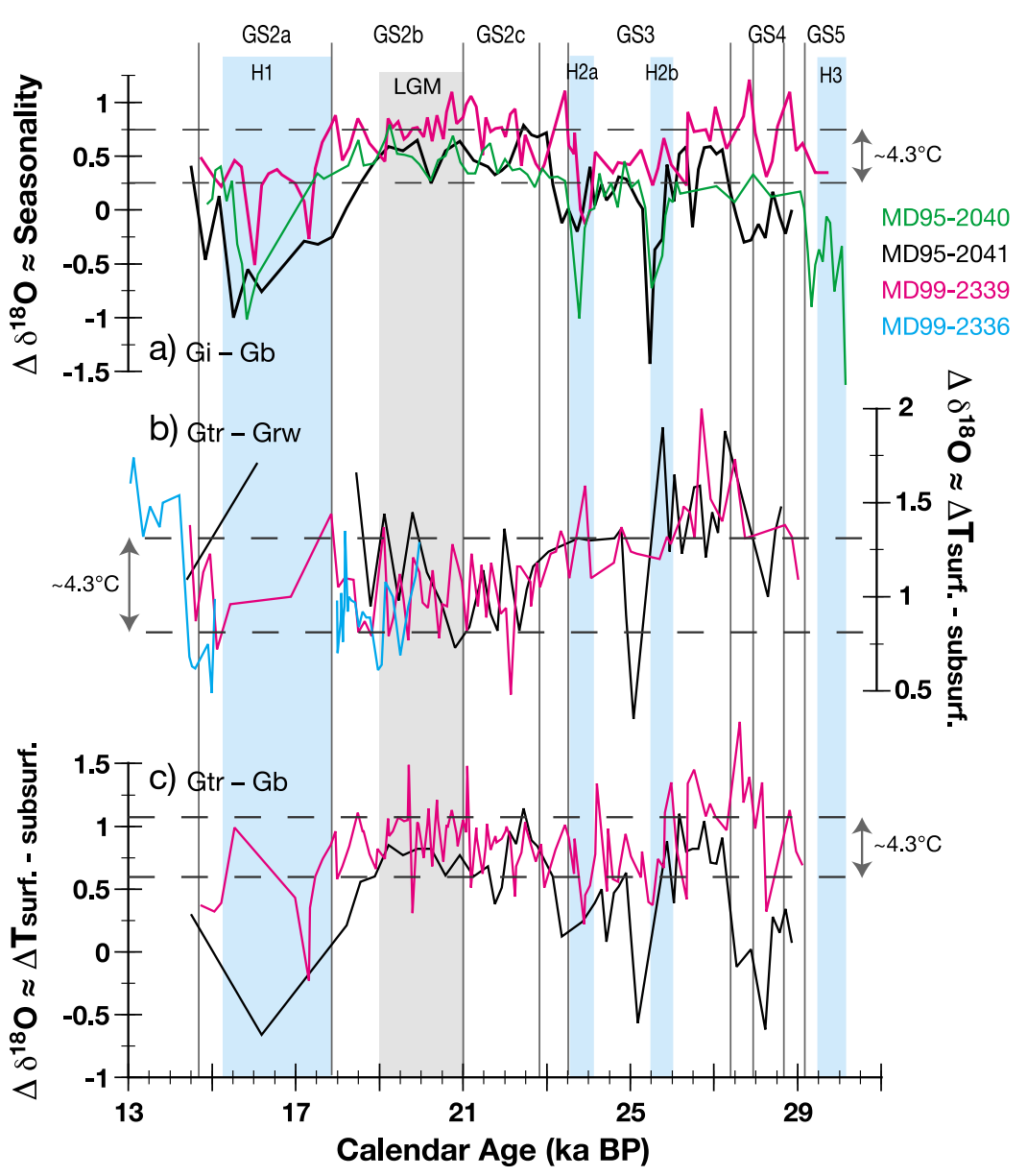

Figure 12. The $\delta^{18} \mathrm{O}$ differences (a) between $G$. inflata and G. bulloides indicate seasonality and (b) between G. truncatulinoides (r) and G. ruber white or (c) G. truncatulinoides ( $\mathrm{r}$ ) and G. bulloides indicate surface to subsurface temperature gradients. Data for core MD95-2040 are shown in green, data for MD95-2041 are shown in black, data for MD99-2336 are shown in light blue, and data for MD99-2339 are shown in magenta. Bars and stratigraphic information are the same as in Figure 8.

values at site MD95-2040 were not much lower than their GS 2b counterparts (Figures 3, 8f, and 11b) and thus indicated a considerable consumption of nutrients. Even further to the north in the Cape Finisterre filament, upwelling-related productivity was reduced during early MIS 2 [Salgueiro et al., 2009]. In the central Gulf of Cadiz, spring to summer export productivity was mostly increased during GS 3 (Figure 11e), in contrast to the LGM. A shift to increased productivity during spring and summer in this region, where productivity normally peaks during the winter bloom [Navarro and Ruiz, 2006], indicated conditions that were quite different from today. The enhanced productivity can be related to either westerly winds prevailing on the southern Portuguese margin, which allowed the plume forming off Cape S. Maria to be more persistent and to extend into the region of core MD99-2339, or dominantly easterly winds leading to a persistent presence of the Strait of Gibraltar filament or a combination of both. Overall, the shift to higher productivity off the southern Portuguese margin indicated that the winds were stronger in the south than in the north during GS 3, potentially linked to a more southern position of the Azores High.

\subsection{Hydrography and Productivity During GS $2 c$ and $2 b$}

[30] The SST records for cores MD95-2040, MD95-2041 and MD99-2339 (Figures 8h, 9h, and $10 \mathrm{~h}$ ) revealed that the LGM as part of GS $2 \mathrm{~b}$ was a period when no major cooling was observed in the nearshore regions along the western Iberian margin. SST were relatively stable and either in the range of the modern SST (Figures $1 \mathrm{~b}$ and 1c) or slightly colder [Bard et al., 2000; Abrantes et al., 2001]. At $40.6^{\circ} \mathrm{N}$ (MD95-2040; Figure 8h), the second half of the LGM was warmer than the first, but less stable. On the southern margin, trends to 
slightly colder SST were observed after 20 to 20.5 cal $\mathrm{ka}$ in cores MD95-2041 (Figure 9h) and MD99-2339 (Figure 10h). Both sites also revealed variable SST conditions during GS 2c. The warming in the Portuguese nearshore waters during the LGM can only be explained by the inflow of subtropical waters, similar to the circulation pattern during modern winters (Figure 1a). This inflow would be promoted by the Azores Front penetrating into the Gulf of Cadiz [Rogerson et al., 2004]. During the LGM and GS 2c, G. ruber white specimens were found in core MD95-2040 (Figure 8b) and even further north at site SU92-03 [Salgueiro, 2006]. Subtropical surface waters were thus transported poleward with the IPC at least until $43^{\circ} \mathrm{N}$. The G. ruber white $\delta^{18} \mathrm{O}$ values of core MD952040 were lighter than those of $G$. bulloides, especially during GS 2c and Greenland interstadial 2. Applying the $\delta^{18} \mathrm{O}$ corrections for G. bulloides and G. ruber white of Wilke et al. [2009] to these values, shifts the $G$. ruber white values during the LGM to higher levels than G. bulloides and merged the records during GS $2 \mathrm{c}$. The offset during Greenland interstadial 2, however, persisted implying a significant warming in the surface mixed layer during winter, because winter is the season of highest $G$. ruber white flux in the Canary Island region [Wilke et al., 2009]. The faunal SSTs indicated winter temperatures of only $10^{\circ} \mathrm{C}$, which is colder than the temperature range for G. ruber white. It is therefore possible that during the LGM the maximum heat transport with the IPC occurred either in early fall (October), when surface waters were still relative warm from summer insolation, or late spring (April) prior to the upwelling season; thus seasons not covered by our faunal SST reconstructions. Also off Sines (MD95-2041; Figure 9b) the uncorrected $\delta^{18} \mathrm{O}$ values of $G$. ruber white and G. bulloides differed slightly during GS $2 \mathrm{c}$ and $2 \mathrm{~b}$, but merged when the respective corrections were applied. Assuming seasons of highest flux remained constant for both species (spring to summer for $G$. bulloides; winter for $G$. ruber white) the similar $\delta^{18} \mathrm{O}$ values can only be explained if the G. ruber white signal is advected from warmer waters to the south or if the G. bulloides values recorded upwelled waters that were colder than the estimated summer SST. Excluding any other effects and interpreting the G. bulloides $\delta^{13} \mathrm{C}$ values as purely reflecting nutrient concentrations they implied sufficient nutrients being available in the upper water column and that would support $G$. bulloides as recording upwelled waters. In the Gulf of Cadiz, uncorrected G. ruber white and G. bulloides values merged at both sites (Figures 5 and 10b). With corrections the $G$. ruber white values were mostly higher than the $G$. bulloides data, in agreement with cooler winter temperatures being recorded by $G$. ruber white. However, the seasonal temperature contrast in the surface mixed layer, as implied by these two species, was smaller (around $0.35 \%=1.5^{\circ} \mathrm{C}$ ) than the one indicated by the faunal SSTs that reveal a summer to winter temperature gradient of $4^{\circ} \mathrm{C}$, equal to nearly $1 \%$ in $\delta^{18} \mathrm{O}$. A smaller seasonal gradient was supported by the $\delta^{18} \mathrm{O}$ difference between $G$. inflata and G. bulloides. During the LGM this temperature difference was $3.2^{\circ} \mathrm{C}$ $(0.74 \%$; Figure $12 \mathrm{a})$ on average and thus smaller than the modern temperature contrast between the summer surface and the winter deep mixed layer in the Gulf of Cadiz $\left(5-6^{\circ} \mathrm{C}\right.$; Figure 2). On the other hand, the smaller seasonal gradient could also indicate that in the Gulf of Cadiz G. bulloides did not reflect summer temperatures. If the isotopic offset is a seasonal temperature signal, then surface water salinities also did not change much in the central Gulf of Cadiz as revealed by the estimated $\delta \mathrm{w}$ values (Figure 10e). This explanation would be in agreement with the modern hydrographic conditions (Figure 2).

[31] The N. pachyderma (r) based $\delta \mathrm{w}$ values of core MD99-2339 (Figure 10e), on the other hand, reflected less saline waters in the subthermocline level in the central Gulf of Cadiz. This signal could be linked to the subsurface salinity minimum of the subtropical ENACW (today around $100 \mathrm{~m}$ water depth; Figure 2). The heavier N. pachyderma (r) $\delta^{18} \mathrm{O}$ values relative to $G$. bulloides (while reduced, the offset remains for corrected values) showed that $N$. pachyderma (r) calcified deeper than G. bulloides (Figures 6 and 10). On the western margin, the lighter $N$. pachyderma (r) $\delta \mathrm{w}$ values were probably also linked to the subsurface salinity minimum. However, since $\delta^{18} \mathrm{O}$ of $G$. bulloides and $N$. pachyderma (r) did not differ much at the western margin sites, calcification depths and growth seasons must have been similar. Off California, a reduced offset between these two species is observed during upwelling [Pak and Kennett, 2002]. Indeed, upwelling was strong during most of GS $2 \mathrm{c}$ and $2 \mathrm{~b}$ at both western margin sites as indicated by the maxima in export productivity (Figures 11c and 11d). Increased productivity during this interval agreed with total alkenone concentration and organic carbon [Pailler and Bard, 2002] and diatom evidences [Abrantes, 1991] indicating that upwelling related productivity and productivity outside of the upwelling filaments 
was enhanced and exceeded Holocene levels [Pailler and Bard, 2002; Salgueiro et al., 2009]. Upwelling was more persistent in the Porto region (MD95-2040) than off Sines (MD95-2041). In the nearshore region off Sines upwelling was interrupted between 20 and 20.5 cal ka and this interval coincided with short periods when export productivity in the central Gulf of Cadiz increased, likewise around 22 cal ka. During short periods of GS $2 c$ and $2 b$ wind patterns in the Gulf of Cadiz region were such that either westerly winds enforced upwelling on the southern margin off Cape S. Maria, potentially allowing this local upwelling plume to merge with a more persistent eastward reflection of the Cape S. Vicente filament, and/or easterly winds induced the formation of the Gulf of Cadiz filament, similar to conditions during most of GS 3. A seesaw pattern in productivity between the southwestern and southern Iberian margin is, however, not seen for the transition from Greenland interstadial 2 to GS 2c $(23.2-22.6 \mathrm{cal} \mathrm{ka})$ when productivity was high in both regions (Figures 11d and 11e). The SST records confirmed colder (warmer) SST for times with increased (decreased) productivity for each core site (Figures 8-10). This concurred with colder waters being upwelled and thus lowering the average seasonal temperatures. The stable isotope $\delta^{18} \mathrm{O}$ data of both cores (Figures 9 and 10) did not indicate any major changes in the water column hydrography along with these shits in productivity. Also the $\delta^{13} \mathrm{C}$ data of the species related to winter conditions (Figures 9f and 10f) did not reveal major changes in the amount of nutrients replenished by deep winter mixing. The G. bulloides $\delta^{13} \mathrm{C}$ values, on the other hand, were relatively low at all four sites (Figures 3-6) during GS 2c and 2b implying that nutrients were plenty and most likely provided by upwelled waters. So the minima in upwelling-related export productivity of core MD95-2041 during parts of GS $2 \mathrm{c}$ and 2b probably had a different reason than failure in upwelling off the southwestern Iberian margin. The most likely cause is a displacement of the Cape Roca and Cape Espichel filaments. The two filaments, today formed north and south of Lisbon and extending down to Sines, were probably displaced offshore because of the shift in coastline due to the lower sea level. A position of the filaments further offshore than today agreed with the evidence from core MD95-2042, located at the same latitude but further offshore than core MD95-2041. Productivity proxy records of core MD95-2042 [Pailler and Bard, 2002] showed some oscillations but no major weakening in the productivity during GS $2 \mathrm{c}$ and $2 \mathrm{~b}$.
[32] Despite the short peaks in productivity described above for core MD99-2339, export productivity during much of GS $2 \mathrm{c}$ and the LGM was low in the central Gulf of Cadiz (Figure 11e). The values were significantly lower than along the western margin. Similar to today, the central Gulf of Cadiz was mostly an oligotrophic region during GS 2c and the LGM. That the lower productivity was not caused by the absence of nutrients in the (sub)surface waters was clearly revealed by the core MD99-2339 record. At this site, the low $N$. pachyderma (r) $\delta^{13} \mathrm{C}$ values (Figure $11 \mathrm{~b}$ ) indicated a high concentration of unused nutrients during times of low export productivity, especially for the period from 22 to $20.5 \mathrm{cal} \mathrm{ka}$. The same link between $N$. pachyderma (r) $\delta^{13} \mathrm{C}$ values and productivity, but less pronounced was also observed for core MD95-2041 between 21 and 20 cal ka (Figure 11).

[33] Conditions in the deep winter mixed layer and below were very stable during the LGM as depicted by the stable isotope records of $G$. inflata, G. scitula, and G. truncatulinoides (r) (Figures 8d, $9 \mathrm{~d}$, and $10 \mathrm{~d})$. G. truncatulinoides $(\mathrm{r}) \delta^{13} \mathrm{C}$ values were heavy and thus indicated relatively fewer nutrients in the ambient waters. This would be typical for the subtropical ENACW. As similar, although more variable, levels were also recorded at site MD95-2040, the subtropical ENACW penetrated as far north as $40.6^{\circ} \mathrm{N}$, most likely as subsurface component of the IPC. Temperature gradients between the surface waters ( $G$. ruber white or G. bulloides) and the ENACW as recorded by $G$. truncatulinoides $(\mathrm{r}) \delta^{18} \mathrm{O}$ were in the range of $4^{\circ} \mathrm{C}$ in the Gulf of Cadiz and off Sines (Figures 12b and $12 \mathrm{c}$ ), and thus similar to the modern gradient during winters. Consequently, it appears that overall hydrographic conditions during GS $2 \mathrm{c}$ and $2 \mathrm{~b}$ along the western Iberian margin were not much different from the present conditions.

[34] During the later phase of GS 2b (19 to $17.8 \mathrm{cal} \mathrm{ka})$, i.e., the interval from the end of the LGM to the onset of the Heinrich event 1 and beginning of GS 2a, hydrographic conditions did not deviate much from the LGM state, but SSTs along the margin became less stable. In the central Gulf of Cadiz this interval starts with a SST minimum and then SST rose toward the base of GS 2a (Figure 10h). At site MD95-2041 (Figure 9h), SST dropped continuously toward GS $2 \mathrm{a}$ and at site MD95-2040 SST stayed relatively warm but were highly variable. This increased variability might be linked to impacts of the freshwater release 
by the first post-LGM sea level rise at $19 \mathrm{cal} \mathrm{ka}$ [Clark et al., 2004] on the AMOC. Productivity was high at all three sites (Figures 11c-11e) indicating that wind patterns during this period were similar to those during GS 3 .

\subsection{Impacts of Heinrich Events and Greenland Stadials on Hydrography and Productivity}

[35] The studied interval encompasses Heinrich events 1, 2a and 2b [Grousset et al., 2000; Bard et al., 2000], and 3 and GS 4 (Figures 8-10). Heinrich event 1 had the highest impact on the hydrography along the western Iberian, while the intensity of the other Heinrich events and the meltwater event during GS 4 varied between events and regionally. At site MD95-2040, which is located north of the southern edge of the North Atlantic's Heinrich IRD belt [Hemming, 2004], all Heinrich events led to significant cooling in the surface waters (Figures $8 \mathrm{~g}$ and $8 \mathrm{~h}$ ). SST dropped abruptly by $8^{\circ} \mathrm{C}$ or more at the onset of Heinrich events $3,2 \mathrm{a}$ and 1 , and by around $5^{\circ} \mathrm{C}$ during Heinrich event $2 \mathrm{~b}$. Minimum SST were around $2^{\circ} \mathrm{C}$ during winter and $6^{\circ} \mathrm{C}$ during summer indicating the presence of Arctic surface waters and that the Polar Front reached the Iberian margin [Eynaud et al., 2009]. GS 4, on the other hand, was only associated with a $2^{\circ} \mathrm{C}$ cooling at site MD95-2040 (Figure $8 \mathrm{~g}$ ). South of the IRD belt, the picture was slightly different. During Heinrich event 1 , subarctic waters reached site MD95-2041 (Figure 9h) only after $17 \mathrm{cal} \mathrm{ka}$, i.e., 500 years later than on the northern margin [de Abreu et al., 2003; Schönfeld et al., 2003; Salgueiro, 2006]. During the earlier Heinrich events subarctic surface waters did not penetrate as far south, except for about a short (120 a) period during Heinrich event 2a. For Heinrich event $2 \mathrm{~b}$ no cooling was observed at all, while cooling during Heinrich event 3 and GS 4 was in the range of $5^{\circ} \mathrm{C}$. During Heinrich event $2 \mathrm{~b}$, the $\% N$. pachyderma (s) increased slightly hinting to some cooling, at least during some of the years. Cooling during Heinrich event $2 b$ was also indicated by the mean annual SST reconstructed for nearby core SU81-18 [Bard et al., 2000], but significant freshening of the surface water is only associated with Heinrich event 2a. A seasonal temperature gradient stronger than the gradient as displayed by the planktonic foraminiferal faunas is also indicated by the dinocyst fauna of core SU81-18 [Turon et al., 2003]. On the other hand, the $\delta \mathrm{w}$ anomalies estimated for core MD95-2041 (Figure 9e) did not show major freshening for
Heinrich events $2 \mathrm{~b}$ and $2 \mathrm{a}$. This indicated that the freshwater lenses associated with the Heinrich events had a stronger impact in the offshore region, raising the question if a hydrographic front separated the sites. In the central Gulf of Cadiz (MD992339; Figure 9h), cooling associated with Heinrich events $2 \mathrm{a}, 2 \mathrm{~b}$, and 3 and GS 4 was minimal. From all of them, Heinrich event 3 had the more pronounced minimum, but subarctic surface waters penetrated into the Gulf of Cadiz only during the colder phases of Heinrich event 1. At site MD992339, the SST records revealed a complex pattern for Heinrich event 1 related to shifts in the position of the Polar Front and associated advances of subarctic waters [Voelker et al., 2006]. Similar to the Sines record of core MD95-2041, subarctic waters reached this more southern latitude only after $17 \mathrm{cal} \mathrm{ka}$. The highest percentage of $N$. pachyderma (s) and thus the coldest part of Heinrich event 1 occurred between 16.5 and 15.2 cal ka concordant with higher IRD deposition at site MD99-2339 [Voelker et al., 2006] and off Sines at site SU81-18 [Bard et al., 2000]. At site MD99-2339 warming to modern SST levels occurred around $15.5 \mathrm{cal} \mathrm{ka}$, i.e., 700 years prior to the onset of Greenland interstadial 1. This early warming and thus the northward receding Polar Front during the latest phase of GS 2a was also recorded further north at site MD95-2040 (Figure 9h). While the coarser resolution of the MD95-2041 record prohibits a clear interpretation in the timing of the post Heinrich event 1 warming, the alkenone SST records of cores SU81-18 [Bard et al., 2000] and MD95-2042 [Pailler and Bard, 2002] both revealed rising SST off Sines around 15 cal ka.

[36] Along with the advances of subarctic waters also freshening occurred, partly caused by icebergs melting close to the sites [de Abreu et al., 2003; Schönfeld et al., 2003; Voelker et al., 2006]. Surface water freshening was strongest during Heinrich event 1 , where the $\delta \mathrm{w}$ records revealed changes of $2 \%$ or more (Figures $8 \mathrm{e}, 9 \mathrm{e}$, and $10 \mathrm{e}$ ), thus in the upper range predicted by Bard et al. [2000]. In all records freshening during Heinrich event 1 was greatest in the later phase (after $16 \mathrm{cal}$ ka) when the presence of hematite-stained grains in the IRD of core SU81-18 [Bard et al., 2000] indicated that icebergs originating from the North American ice sheet were melting off western Iberia. The strong freshening implies the establishment of a halocline. The halocline would separate the surface mixed layer from the subsurface waters and this would explain why the deep dweller 
planktonic foraminifer fauna was so diminished during the Heinrich events, especially along the western margin (Figures $8 \mathrm{~g}, 9 \mathrm{~g}$, and $10 \mathrm{~g}$ ). $\delta^{18} \mathrm{O}$ values of $G$. bulloides, $N$. pachyderma (r) and $N$. pachyderma (s) were close together indicating that the surface layer, in which these species calcified, was well mixed, similar to the observations of Rashid and Boyle [2007] in the Azores region. The slight separation between $N$. pachyderma $(\mathrm{r})$ and $N$. pachyderma (s) during Heinrich event 1 at site MD95-2041 (Figure 9c) might indicate that $N$. pachyderma (s), which prefers a certain temperature range, lived slightly deeper than N. pachyderma (r), perhaps similar to the modern situation in the Nordic seas [Simstich, 1999; Simstich et al., 2003].

[37] The presence of the deeper living subtropical coccolith species Florisphaera profunda in the Gulf of Cadiz during the Heinrich events [ColmeneroHidalgo et al., 2004] revealed the presence of subtropical ENACW underneath the halocline. Thus the few G. truncatulinoides (r) data points acquired during Heinrich events in cores MD952041 (Figures 4 and 9d), MD99-2336 (Figure 5) and MD99-2339 (Figures 6 and 10d) most likely reflected conditions in this subsurface layer, conform with their $\delta^{13} \mathrm{C}$ values not being much different from the rest of MIS 2 (Figures 5, 9f, and 10f). The presence of warmer subsurface waters would also explain the large $\delta^{18} \mathrm{O}$ difference between $G$. bulloides and G. truncatulinoides (r) observed during the Heinrich events (Figure 12c). The difference between G. inflata and G. bulloides, which has similar ranges (Figure 12a), most probably mirrored a surface to subsurface temperature gradient during Heinrich events and not a seasonal temperature gradient like during GS $2 \mathrm{c}$ and $2 \mathrm{~b}$. The sporadic presence of $G$. ruber white during Heinrich event 1 prior to the warming after $15.5 \mathrm{cal}$ ka seems to indicate that for short periods subtropical surface waters were present in the Gulf of Cadiz. During those periods, the surface to subsurface temperature gradient (Figure 12b) was not that much different from today.

[38] The extremely light G. truncatulinoides (r) $\delta^{18} \mathrm{O}$ values measured in core MD95-2040 during Heinrich events $2 \mathrm{a}, 2 \mathrm{~b}$ and 3 and between Heinrich event $2 \mathrm{a}$ and $2 \mathrm{~b}$ are puzzling. Since abundances during these intervals are so low (Figure 8f), bioturbational mixing could be one cause [Löwemark et al., 2008]. In general, G. truncatulinoides (r) $\delta^{18} \mathrm{O}$ values were heavier and comparable to those measured at the sites to the south outside of these intervals. Lototskaya and Ganssen [1999] explained their unusually light $G$. truncatulinoides values during Termination 2 as an allochthonous signal due to long-distance transport of specimens. However, since the southern records did not show such light values, advection from the subtropical gyre seems less likely. The G. truncatulinoides (r) shells analyzed in core MD95-2040 were generally thin, missing the gametogenic crust laid down in the deeper water column [Lohmann and Schweitzer, 1990]. They had the compressed shape of the shells typical for the cold-water type [de Vargas et al., 2001]. This type tends to calcify in shallower depths than the warm water one. Lončarić et al. [2006] also observed that the smaller $G$. truncatulinoides tests were calcified higher up in the water column than their larger counterparts. So the light isotopic values could either be related to environmental stress or indicate calcification in less saline waters, may be in a subpolar mode water formed closed to the edges of the Celtic-British-Amorican ice sheets, which calved especially during Heinrich event $2 \mathrm{a}$ [Grousset et al., 2000; Knutz et al., 2001; Peck et al., 2006], and advected southward to the study site. Anyhow, these light values should be treated with caution.

[39] Besides the hydrography, Heinrich events and GS 4 meltwater event also strongly affected the productivity along the western Iberian margin (Figure 11). In the upwelling systems on the western margin, the presence of a strong halocline inhibited productivity. This observation is conform to what the model of Schmittner [2005] predicts for the open North Atlantic but in contradiction to the model's results for the Portuguese margin. In the central Gulf of Cadiz, productivity increased during all Heinrich events and GS 4 (Figure 11e). Some of the increased productivity might be linked to easterly winds and a more permanent presence of the Strait of Gibraltar filament. The wind pattern reconstructed by Daniau et al. [2007] for Heinrich events indicated easterly winds in the Gulf of Cadiz region. In addition to the wind driven upwelling, frontal upwelling along the Azores front, penetrating into the Gulf of Cadiz [Rogerson et al., 2004], might also have played a role. During Heinrich events the planktonic foraminifer fauna in core MD99-2339 was dominated by $G$. bulloides and T. quinqueloba (A. H. L. Voelker, unpublished data, 2004). Higher abundances of T. quinqueloba mark the Arctic Front in the Nordic seas [Johannessen et al., 1994] and in the Fram Strait they were observed close to the sea ice margin where food (diatom) flux was higher [Carstens et al., 1997]. The G. bulloides and N. pachyderma $(\mathrm{r}) \delta^{18} \mathrm{O}$ values 
in core MD99-2339 were generally heavier during the Heinrich events and some of that cooling could also be related to upwelling of colder waters, especially during Heinrich event $2 \mathrm{~b}$. The high productivity entirely consumed the nutrients available in the surface mixed layer as evidenced by the relatively heavy $N$. pachyderma $(\mathrm{r}) \delta^{13} \mathrm{C}$ values (Figure 11b).

\section{Conclusions}

[40] During the LGM, hydrographic conditions along the western Iberian margin were similar to the present, even though climate forcing was very different. Subtropical surface and subsurface water penetrated northward along the western margin probably equal to the modern winter circulation. Seasonal temperature gradients between the summer and winter mixed layers might have been slightly lower than today, but surface to subsurface gradients during winter were similar to today. Upwelling related productivity was elevated along the western margin during GS $2 \mathrm{c}$ and $2 \mathrm{~b}$ (including the LGM), but at the nearshore location off Sines, core MD95-2041, variability was high. Productivity maxima in the Gulf of Cadiz often coincided with minima in the nearshore region off Sines. While dominant wind directions might play a role in this apparent seesaw patterns, offshore displacement of the filament affecting the Sines area is more likely the cause.

[41] Heinrich events had a profound impact on the hydrography and productivity along the margin, especially at the northern site MD95-2040. Subarctic surface waters always affected this site during Heinrich events, but not during GS 3 and 4. Further south off Sines (MD95-2041), only Heinrich event 1 was associated with subarctic water, while cooling was only half as much as at the northern site indicating that during those older Heinrich events the Polar Front migrated less to the south than during Heinrich event 1. Even during Heinrich event 1 , the advance of subarctic waters to the southwestern and southern margin was, within age uncertainties, delayed by 500 years. In the central Gulf of Cadiz, only Heinrich event 1 and to some extent also Heinrich event 3 left a significant imprint in the SST signal. Heinrich event 1 was, however, a period with major shifts in the prevailing surface water masses [Voelker et al., 2006]. Surface water freshening during Heinrich events was significant and led to the formation of a halocline. Especially, in the Gulf of Cadiz and to some extent also on the southwestern margin subtropical ENACW was present underneath the halocline. On the western margin the halocline inhibited upwelling, in contrast to the model predictions of Schmittner [2005] for this region. In the central Gulf of Cadiz, where stratification was less strong, upwelling related productivity peaked during Heinrich events and part of the GS, probably as result of wind-driven and frontal upwelling. This upwelling is in agreement with model results of Schmittner [2005].

\section{Acknowledgments}

[42] A. Voelker thanks Monika Segl and her team for training and supporting her during her stay at Marum (Bremen, Germany) in spring 2002 funded by the Access to Research Infrastructures Activity of the Human Potential Programme of the European Community Paleostudies program. She furthermore acknowledges the financial support by the Fundação para a Ciência e a Tecnologia (FCT) through the project MOWFADRI (PDCTM/PP/MAR/1529/99). The staff of the Laboratorio de Geologia Marinha is thanked for their support in preparing the samples of cores MD99-2236 and MD992339 and S. Lebreiro is appreciated for earlier discussion on the results. L. de Abreu was supported by FCT through postdoctoral fellowship SFRH/BPD/1588/2000 and thanks the late Nick Shackleton for his many years of support and encouragement and Mike Hall. J. Schönfeld was supported by the Deutsche Forschungsgemeinschaft (grants Za157/16-1 and Ti240/9). Yvon Balut, IPEV, and the captains and crews during IMAGES cruises I and $\mathrm{V}$ are thanked for their support in retrieving the Calypso piston cores.

\section{References}

Abrantes, F. (1991), Increased upwelling off Portugal during the last glaciation: Diatom evidence, Mar. Micropaleontol., 17, 285-310, doi:10.1016/0377-8398(91)90017-Z.

Abrantes, F. (1992), Paleoproductivity oscillations during the last $130 \mathrm{ka}$ along the Portuguese and NW African margins, in Upwelling Systems: Evolution Since the Early Miocene, edited by C. P. Summerhayes, W. L. Prell, and K. C. Emeis, Geol. Soc. Spec. Publ., 64, 499-510.

Abrantes, F., N. Lončarić, J. Moreno, M. Mil-Homens, and U. Pflaumann (2001), Paleoceanographic conditions along the Portuguese Margin during the last $30 \mathrm{ka}$ : A multiple proxy study, Comun. Inst. Geol. Min., 88, 161-184.

Alvarez-Salgado, X. A., et al. (2003), The Portugal coastal counter current off NW Spain: New insights on its biogeochemical variability, Prog. Oceanogr., 56(2), 281-321, doi:10.1016/S0079-6611(03)00007-7.

Ambar, I., N. Serra, M. J. Brogueira, G. Cabecadas, F. Abrantes, P. Freitas, C. Goncalves, and N. Gonzalez (2002), Physical, chemical and sedimentological aspects of the Mediterranean outflow off Iberia, Deep Sea Res., Part II, 49(19), 41634177, doi:10.1016/S0967-0645(02)00148-0.

Andersen, K. K., et al. (2006), The Greenland Ice Core Chronology 2005, 15-42 ka. Part 1: Constructing the time scale, Quat. Sci. Rev., 25(23-24), 3246-3257, doi:10.1016/ j.quascirev.2006.08.002. 
Antoine, D., J.-M. André, and A. Morel (1996), Oceanic primary production: 2. Estimation at global scale from satellite (coastal zone color scanner) chlorophyll, Global Biogeochem. Cycles, 10(1), 57-70, doi:10.1029/95GB02832.

Bard, E., F. Rostek, J.-L. Turon, and S. Gendreau (2000), Hydrological impact of Heinrich events in the subtropical northeast Atlantic, Science, 289, 1321-1324, doi:10.1126/ science.289.5483.1321.

Bard, E., F. Rostek, and G. Menot-Combes (2004), Radiocarbon calibration beyond $20,000{ }^{14} \mathrm{C}$ yr B.P. by means of planktonic foraminifera of the Iberian Margin, Quat. Res., 61(2), 204-214, doi:10.1016/j.yqres.2003.11.006.

Bassinot, F., and L. Labeyrie (1996), IMAGES MD 101: A Coring Cruise of the $R / V$ Marion Dufresne in the North Atlantic and Norwegian Sea, 217 pp., Inst. Fr. pour la Rech. et la Technol. Polaires, Plouzané, France.

Bemis, B. E., H. J. Spero, J. Bijma, and D. W. Lea (1998), Reevaluation of the oxygen isotopic composition of planktonic foraminifera: Experimental results and revised paleotemperature equations, Paleoceanography, 13(2), 150-160, doi:10.1029/98PA00070.

Bemis, B. E., H. J. Spero, D. W. Lea, and J. Bijma (2000), Temperature influence on the carbon isotopic composition of Globigerina bulloides and Orbulina universa (planktonic foraminifera), Mar. Micropaleontol., 38, 213-228, doi:10.1016/S0377-8398(00)00006-2.

Berger, W. H., V. S. Smetacek, and G. Wefer (1989), Productivity of the Ocean: Present and Past, Report of the Dahlem Workshop on Productivity of the Ocean: Present and Past, Berlin, 1988, April 24-29, John Wiley, Chichester, U. K.

Bond, G., et al. (1992), Evidence for massive discharge of icebergs into the glacial North Atlantic, Nature, 360, 245249, doi:10.1038/360245a0.

Bond, G. C., W. Showers, M. Elliot, M. Evans, R. Lotti, I. Hajdas, G. Bonani, and S. Johnson (1999), The North Atlantic's 1-2 kyr climate rhythm: Relation to Heinrich events, Dansgaard/Oeschger cycles and the Little Ice Age, in Mechanisms of Global Climate Change at Millennial Time Scales, Geophys. Monogr. Ser., vol. 112, edited by P. U. Clark, R. S. Webb, and L. D. Keigwin, pp. 35-58, AGU, Washington, D. C.

Braconnot, P., et al. (2007), Results of PMIP2 coupled simulations of the Mid-Holocene and Last Glacial MaximumPart 1: Experiments and large-scale features, Clim. Past, 3(2), 261-277.

Broecker, W. S., and T.-H. Peng (1982), Tracers in the Sea, 690 pp., ELDIGIO Press, Lamont-Doherty Geol. Obs., Columbia Univ., Palisades, N. Y.

Carstens, J., D. Hebbeln, and G. Wefer (1997), Distribution of planktic foraminifera at the ice margin in the Arctic (Fram Strait), Mar. Micropaleontol., 29(3-4), 257-269, doi:10.1016/S0377-8398(96)00014-X.

Clark, P. U., A. M. McCabe, A. C. Mix, and A. J. Weaver (2004), Rapid rise of sea level 19,000 years ago and its global implications, Science, 304(5674), 1141-1144, doi:10.1126/science.1094449.

Cléroux, C., E. Cortijo, J.-C. Duplessy, and R. Zahn (2007), Deep-dwelling foraminifera as thermocline temperature recorders, Geochem. Geophys. Geosyst., 8, Q04N11, doi:10.1029/2006GC001474.

Colmenero-Hidalgo, E., J.-A. Flores, F. J. Sierro, M. A. Barcena, L. Löwemark, J. Schoenfeld, and J. O. Grimalt (2004), Ocean surface water response to short-term climate changes revealed by coccolithophores from the Gulf of Cadiz (NE Atlantic) and Alboran Sea (W Mediterranean),
Palaeogeogr. Palaeoclimatol. Palaeoecol., 205(3-4), 317-336, doi:10.1016/j.palaeo.2003.12.014.

Daniau, A. L., M. F. Sánchez-Goñi, L. Beaufort, F. LaggounDefarge, M. F. Loutre, and J. Duprat (2007), DansgaardOeschger climatic variability revealed by fire emissions in southwestern Iberia, Quat. Sci. Rev., 26(9-10), 1369-1383, doi:10.1016/j.quascirev.2007.02.005.

de Abreu, L., N. J. Shackleton, J. Schoenfeld, M. Hall, and M. Chapman (2003), Millennial-scale oceanic climate variability off the western Iberian margin during the last two glacial periods, Mar. Geol., 196(1-2), 1-20, doi:10.1016/ S0025-3227(03)00046-X

de Vargas, C., S. Renaud, H. Hilbrecht, and J. Pawlowski (2001), Pleistocene adaptive radiation in Globorotalia truncatulinoides: Genetic, morphologic, and environmental evidence, Paleobiology, 27(1), 104-125, doi:10.1666/00948373(2001)027<0104:PARIGT>2.0.CO;2.

Duplessy, J.-C., L. Labeyrie, A. Juillet-Leclerc, F. Maitre, J. Duprat, and M. Sarnthein (1991), Surface salinity reconstruction of the North Atlantic Ocean during the last glacial maximum, Oceanol. Acta, 14(4), 311-324.

Eppley, R. W., and B. J. Peterson (1979), Particulate organicmatter flux and planktonic new production in the deep ocean, Nature, 282(5740), 677-680, doi:10.1038/282677a0.

Eynaud, F., et al. (2009), Position of the Polar Front along the western Iberian margin during key cold episodes of the last $45 \mathrm{ka}$, Geochem. Geophys. Geosyst., 10, Q07U05, doi:10.1029/2009GC002398.

Fiúza, A. F. G. (1984), Hidrologia e Dinamica das Aguas Costeiras de Portugal, doctorate thesis, 294 pp., Univ. de Lisboa, Lisbon.

Fiúza, A. F. G., M. Hamann, I. Ambar, G. D. del Rio, N. Gonzalez, and J. M. Cabanas (1998), Water masses and their circulation off western Iberia during May 1993, Deep Sea Res., Part I, 45(7), 1127-1160, doi:10.1016/S09670637(98)00008-9.

Flückiger, J., R. Knutti, J. W. C. White, and H. Renssen (2008), Modeled seasonality of glacial abrupt climate events, Clim. Dyn., 31(6), 633-645, doi:10.1007/s00382008-0373-y.

Folkard, A. M., P. A. Davies, A. F. G. Fiúza, and I. Ambar (1997), Remotely sensed sea surface thermal patterns in the Gulf of Cadiz and the Strait of Gibraltar: Variability, correlations, and relationships with the surface wind field, J. Geophys. Res., 102(C3), 5669-5683, doi:10.1029/ 96JC02505.

Frouin, R., A. F. G. Fiúza, I. Ambar, and T. J. Boyd (1990), Observations of a poleward surface current off the coasts of Portugal and Spain during winter, J. Geophys. Res., 95(C1), 679-691, doi:10.1029/JC095iC01p00679.

Ganssen, G. M., and D. Kroon (2000), The isotopic signature of planktonic foraminifera from NE Atlantic surface sediments: Implications for the reconstruction of past oceanic conditions, J. Geol. Soc., 157, 693-699.

Garcia-Lafuente, J., J. Delgado, F. Criado-Aldeanueva, M. Bruno, J. del Rio, and J. Miguel Vargas (2006), Water mass circulation on the continental shelf of the Gulf of Cadiz, Deep Sea Res., Part II, 53(11-13), 1182-1197, doi:10.1016/j.dsr2.2006.04.011.

Grousset, F. E., C. Pujol, L. Labeyrie, G. Auffret, and A. Boelaert (2000), Were the North Atlantic Heinrich events triggered by the behavior of the European ice sheets?, Geology, $28,123-126$, doi:10.1130/0091-7613(2000) $28<123$ : WTNAHE $>2.0 . \mathrm{CO} ; 2$. 
Haynes, R., and E. D. Barton (1990), A poleward flow along the Atlantic coast of the Iberian Peninsula, J. Geophys. Res., 95(C7), 11,425-11,441, doi:10.1029/JC095iC07p11425.

Haynes, R., E. D. Barton, and I. Pilling (1993), Development, persistence, and variability of upwelling filaments off the Atlantic coast of the Iberian Peninsula, J. Geophys. Res., 98(C12), 22,681-22,692, doi:10.1029/93JC02016.

Heinrich, H. (1988), Origin and consequences of cyclic ice rafting in the northeast Atlantic Ocean during the past 130,000 yrs, Quat. Res., 29, 142-152, doi:10.1016/00335894(88)90057-9.

Hemleben, C., M. Spindler, and O. R. Anderson (1989), Modern Planktonic Foraminifera, 363 pp., Springer, Berlin.

Hemming, S. R. (2004), Heinrich events: Massive late Pleistocene detritus layers of the North Atlantic and their global climate imprint, Rev. Geophys., 42, RG1005, doi:10.1029/ 2003RG000128.

Hillaire-Marcel, C., A. de Vernal, L. Candon, and G. Bilodeau (2001), Changes of potential density gradients in the northwestern North Atlantic during the last climatic cycle based on a multiproxy approach, in The Oceans and Rapid Climate Change: Past, Present, and Future, Geophys. Monogr. Ser., vol. 126, edited by D. Seidov, B. J. Haupt, and M. Maslin, pp. 83-100, AGU, Washington, D. C.

Hughen, K., S. Lehman, J. Southon, J. Overpeck, O. Marchal, C. Herring, and J. Turnbull (2004), ${ }^{14} \mathrm{C}$ activity and global carbon cycle changes over the past 50,000 years, Science, 303(5655), 202-207, doi:10.1126/science.1090300.

Hut, G. (1987), Stable isotope reference samples for geochemical and hydrological investigations, 42 pp., Int. At. Energy Agency, Vienna.

Itou, M., T. Ono, T. Oba, and S. Noriki (2001), Isotopic composition and morphology of living Globorotalia scitula: A new proxy of sub-intermediate ocean carbonate chemistry?, Mar. Micropaleontol., 42, 189-210, doi:10.1016/S03778398(01)00015-9.

Jia, Y. (2000), Formation of an Azores current due to Mediterranean overflow in a modeling study of the North Atlantic, J. Phys. Oceanogr., 30, 2342-2358, doi:10.1175/15200485(2000)030<2342:FOAACD $>2.0 . C O ; 2$.

Johannessen, T., E. Jansen, A. Flatøy, and A. C. Ravelo (1994), The relationship between surface water masses, oceanographic fronts and paleoclimatic proxies in surface sediments of the Greenland, Iceland, Norwegian seas, in Carbon Cycling in the Glacial Ocean: Constraints on the Ocean's Role in Global Change, edited by R. Zahn et al., pp. 61-85, Springer, Berlin.

Johnson, J., and I. Stevens (2000), A fine resolution model of the eastern North Atlantic between the Azores, the Canary Islands and the Gibraltar Strait, Deep Sea Res., Part I, 47(5), 875-899, doi:10.1016/S0967-0637(99)00073-4.

Kageyama, M., et al. (2006), Last Glacial Maximum temperatures over the North Atlantic, Europe and western Siberia: A comparison between PMIP models, MARGO sea-surface temperatures and pollen-based reconstructions, Quat. Sci. Rev., 25(17-18), 2082-2102, doi:10.1016/j.quascirev. 2006.02.010.

King, A. L., and W. R. Howard (2005), $\delta^{18} \mathrm{O}$ seasonality of planktonic foraminifera from Southern Ocean sediment traps: Latitudinal gradients and implications for paleoclimate reconstructions, Mar. Micropaleontol., 56(1-2), 1-24, doi:10.1016/j.marmicro.2005.02.008.

Kjellström, E., J. Brandefelt, J. O. Näslund, B. Smith, G. Strandberg, and B. Wohlfarth (2009), Climate conditions in Sweden in a 100,000 year time perspective, Tech. Rep.
TR-09-04, 130 pp., Svensk Kärnbränslehantering AB, Stockholm.

Knutz, P. C., W. E. N. Austin, and E. J. W. Jones (2001), Millennial-scale depositional cycles related to British Ice Sheet variability and North Atlantic paleocirculation since 45 kyr B.P., Barra Fan, U.K. margin, Paleoceanography, 16(1), 53-64, doi:10.1029/1999PA000483.

Kohfeld, K. E., R. F. Anderson, and J. Lynch-Stieglitz (2000), Carbon isotopic disequilibrium in polar planktonic foraminifera and its impact on modern and Last Glacial Maximum reconstructions, Paleoceanography, 15(1), 53-64, doi:10.1029/1999PA900049.

Kucera, M., M. Weinelt, T. Kiefer, U. Pflaumann, A. Hayes, M. Weinelt, M.-T. Chen, A. C. Mix, T. T. Barrows, and E. Cortijo (2005), Reconstruction of sea-surface temperatures from assemblages of planktonic foraminifera: Multitechnique approach based on geographically constrained calibration data sets and its application to glacial Atlantic and Pacific oceans, Quat. Sci. Rev., 24(7-9), 951-998, doi:10.1016/j.quascirev.2004.07.014.

Labeyrie, L., , E. Jansen, and E. Cortijo(Eds.) (2003), MD 114/ IMAGES $V$, á bord du Marion Dufresne, Fort de France, 11 Juin 1999-Marseille, 20 Septembre 1999, 849 pp., Inst. Polaire Fr. Paul-Emile Victor, Plouzané, France.

Legrende, L., and J. le Fevre (1989), Hydrodynamical singularities as controls of recycled and export production in oceans, in Productivity of the Ocean: Present and Past, Report of the Dahlem Workshop on Productivity of the Ocean: Present and Past, Berlin, 1988, April 24-29, edited by W. H. Berger, V. S. Smetacek, and G. Wefer, pp. 43-65, John Wiley, Chichester, U. K.

Llave, E., J. Schonfeld, F. J. Hernandez-Molina, T. Mulder, L. Somoza, V. Diaz del Rio, and I. Sanchez-Almazo (2006), High-resolution stratigraphy of the Mediterranean outflow contourite system in the Gulf of Cadiz during the late Pleistocene: The impact of Heinrich events, Mar. Geol., 227(3-4), 241-262, doi:10.1016/j.margeo.2005.11.015.

Lohmann, G. P. (1995), A model for variation in the chemistry of planktonic foraminifera due to secondary calcification and selective dissolution, Paleoceanography, 10(3), 445-458, doi:10.1029/95PA00059.

Lohmann, G. P., and P. N. Schweitzer (1990), Globorotalia truncatulinoides: Growth and chemistry as probes of the past thermocline. 1. Shell size, Paleoceanography, 5, 55-75, doi:10.1029/PA005i001p00055.

Lončarić, N., F. J. C. Peeters, D. Kroon, and G.-J. A. Brummer (2006), Oxygen isotope ecology of recent planktic foraminifera at the central Walvis Ridge (SE Atlantic), Paleoceanography, 21, PA3009, doi:10.1029/2005PA001207.

Lototskaya, A., and G. M. Ganssen (1999), The structure of Termination II (penultimate deglaciation and Eemian) in the North Atlantic, Quat. Sci. Rev., 18(14), 1641-1654, doi:10.1016/S0277-3791(99)00011-6.

Lowe, J. J., S. O. Rasmussen, S. Björck, W. Z. Hoek, J. P. Steffensen, M. J. C. Walker, and Z. C. Yu (2008), Synchronisation of palaeoenvironmental events in the North Atlantic region during the Last Termination: A revised protocol recommended by the INTIMATE group, Quat. Sci. Rev. 27(1-2), 6-17, doi:10.1016/j.quascirev.2007.09.016.

Löwemark, L., and F. Werner (2001), Dating errors in highresolution stratigraphy: A detailed X-ray radiograph and AMS ${ }^{14} \mathrm{C}$ study of Zoophycus burrows, Mar. Geol., 177, 191-198, doi:10.1016/S0025-3227(01)00167-0.

Löwemark, L., J. Schoenfeld, F. Werner, and P. Schaefer (2004), Trace fossils as a paleoceanographic tool: Evidence 
from Late Quaternary sediments of the southwestern Iberian margin, Mar. Geol., 204(1-2), 27-41, doi:10.1016/S00253227(03)00351-7.

Löwemark, L., K. I. Konstantinou, and S. Steinke (2008), Bias in foraminiferal multispecies reconstructions of paleohydrographic conditions caused by foraminiferal abundance variations and bioturbational mixing: A model approach, Mar. Geol., 256(1-4), 101-106, doi:10.1016/j.margeo.2008. 10.005 .

MARGO Project Members (2009), Constraints on the magnitude and patterns of ocean cooling at the Last Glacial Maximum, Nat. Geosci., 2(2), 127-132, doi:10.1038/ ngeo411.

McCartney, M. S., and L. D. Talley (1982), The Subpolar Mode Water of the North Atlantic Ocean, J. Phys. Oceanogr., 12(11), 1169-1188, doi:10.1175/1520-0485(1982)012< 1169:TSMWOT>2.0.CO;2.

McManus, J. F., R. Francois, J.-M. Gherardi, L. D. Keigwin, and S. Brown-Leger (2004), Collapse and rapid resumption of Atlantic meridional circulation linked to deglacial climate changes, Nature, 428(6985), 834-837, doi:10.1038/ nature 02494

Meese, D. A., R. B. Alley, A. J. Gow, P. M. Grootes, P. A. Mayewski, M. Ram, K. C. Taylor, E. D. Waddington, and G. A. Zielinski (1994), Preliminary depth-age scale of the GISP2 ice core, 66 pp., Cold Reg. Res. and Eng. Lab., Hanover, N. H.

Mix, A. C., E. Bard, and R. Schneider (2001), Environmental processes of the ice age: Land, oceans, glaciers (EPILOG), Quat. Sci. Rev., 20, 627-657, doi:10.1016/S0277-3791(00) 00145-1.

Mortyn, P. G., and C. D. Charles (2003), Planktonic foraminiferal depth habitat and $\delta^{18} \mathrm{O}$ calibrations: Plankton tow results from the Atlantic sector of the Southern Ocean, Paleoceanography, 18(2), 1037, doi:10.1029/2001PA000637.

Mulitza, S., A. Dürkoop, W. Hale, G. Wefer, and H. S. Niebler (1997), Planktonic Foraminifera as recorders of past surfacewater stratification, Geology, 25(4), 335-338, doi:10.1130/ 0091-7613(1997)025<0335:PFAROP >2.3.CO;2.

Mulitza, S., D. Boltovskoy, B. Donner, H. Meggers, A. Paul, and G. Wefer (2003), Temperature: $\delta^{18} \mathrm{O}$ relationships of planktonic foraminifera collected from surface water, Palaeogeogr. Palaeoclimatol. Palaeoecol., 202, 143-152, doi:10.1016/S0031-0182(03)00633-3.

Navarro, G., and J. Ruiz (2006), Spatial and temporal variability of phytoplankton in the Gulf of Cadiz through remote sensing images, Deep Sea Res., Part II, 53(11-13), 12411260, doi:10.1016/j.dsr2.2006.04.014.

Nave, S., L. Labeyrie, J. Gherardi, N. Caillon, E. Cortijo, C. Kissel, and F. Abrantes (2007), Primary productivity response to Heinrich events in the North Atlantic Ocean and Norwegian Sea, Paleoceanography, 22, PA3216, doi:10.1029/2006PA001335.

Ortiz, J. D., A. C. Mix, W. Rugh, J. M. Watkins, and R. W. Collier (1996), Deep-dwelling planktonic foraminifera of the northeastern Pacific Ocean reveal environmental control of oxygen and carbon isotopic disequilibria, Geochim. Cosmochim. Acta, 60(22), 4509-4523, doi:10.1016/S0016-7037(96) 00256-6.

Ottens, J. J. (1991), Planktic foraminifera as North Atlantic water mass indicators, Oceanol. Acta, 14(2), 123-140.

Otto-Bliesner, B. L., C. D. Hewitt, T. M. Marchitto, E. Brady, A. Abe-Ouchi, M. Crucifix, S. Murakami, and S. L. Weber (2007), Last Glacial Maximum ocean thermohaline circulation: PMIP2 model intercomparisons and data con- straints, Geophys. Res. Lett., 34, L12706, doi:10.1029/ 2007GL029475.

Özgökmen, T. M., E. P. Chassignet, and C. G. H. Rooth (2001), On the connection between the Mediterranean Outflow and the Azores Current, J. Phys. Oceanogr., 31, 461480, doi:10.1175/1520-0485(2001)031<0461:OTCBTM> 2.0.CO;2.

Pailler, D., and E. Bard (2002), High frequency palaeoceanographic changes during the past $140000 \mathrm{yr}$ recorded by the organic matter in sediments of the Iberian Margin, Palaeogeogr. Palaeoclimatol. Palaeoecol., 181(4), 431-452, doi:10.1016/S0031-0182(01)00444-8.

Pak, D. K., and J. P. Kennett (2002), A foraminiferal isotopic proxy for upper water mass stratification, J. Foraminiferal Res., 32(3), 319-327, doi:10.2113/32.3.319.

Peck, V. L., I. R. Hall, R. Zahn, H. Elderfield, F. Grousset, S. R. Hemming, and J. D. Scourse (2006), High resolution evidence for linkages between NW European ice sheet instability and Atlantic Meridional Overturning Circulation, Earth Planet. Sci. Lett., 243(3-4), 476-488, doi:10.1016/ j.epsl.2005.12.023.

Peeters, F. J. C., G.-J. A. Brummer, and G. Ganssen (2002), The effect of upwelling on the distribution and stable isotope composition of Globigerina bulloides and Globigerinoides ruber (planktic foraminifera) in modern surface waters of the NW Arabian Sea, Global Planet. Change, 34, 269-291, doi:10.1016/S0921-8181(02)00120-0.

Peliz, A., J. Dubert, A. M. P. Santos, P. B. Oliveira, and B. Le Cann (2005), Winter upper ocean circulation in the Western Iberian Basin-Fronts, eddies and poleward flows: An overview, Deep Sea Res., Part I, 52(4), 621-646, doi:10.1016/ j.dsr.2004.11.005.

Peliz, A., A. Teles-Machado, P. Marchesiello, J. Dubert, and J. G. Lafuente (2009), Filament generation off the Strait of Gibraltar in response to Gap winds, Dyn. Atmos. Oceans, 46(1-4), 36-45, doi:10.1016/j.dynatmoce.2008.08.002.

Penduff, T., A. C. de Verdiere, and B. Barnier (2001), General circulation and intergyre dynamics in the eastern North Atlantic from a regional primitive equation model, J. Geophys. Res., 106(C10), 22,313-22,329, doi:10.1029/ $2000 J C 000346$.

Perez, F. F., C. G. Castro, X. A. Alvarez-Salgado, and A. F. Rios (2001), Coupling between the Iberian basin-scale circulation and the Portugal boundary current system: A chemical study, Deep Sea Res., Part I, 48(6), 1519-1533, doi:10.1016/S0967-0637(00)00101-1.

Pflaumann, U., J. Duprat, C. Pujol, and L. D. Labeyrie (1996), SIMMAX: A modern analog technique to deduce Atlantic sea surface temperatures from planktonic foraminifera in deep-sea sediments, Paleoceanography, 11(1), 15-36, doi:10.1029/95PA01743.

Pflaumann, U., et al. (2003), Glacial North Atlantic: Seasurface conditions reconstructed by GLAMAP 2000, Paleoceanography, 18(3), 1065, doi:10.1029/2002PA000774.

Pingree, R. D., C. Garcia-Soto, and B. Sinha (1999), Position and structure of the Subtropical/Azores Front region from combined Lagrangian and remote sensing (IR/altimeter/ SeaWiFS) measurements, J. Mar. Biol. Assoc. U. K., 79(5), 769-792, doi:10.1017/S002531549900096X.

Rashid, H., and E. A. Boyle (2007), Mixed-layer deepening during Heinrich events: A multi-planktonic foraminiferal $\delta^{18} \mathrm{O}$ approach, Science, 318(5849), 439-441, doi:10.1126/ science. 1146138 .

Reimer, P. J., et al. (2004), INTCAL04 terrestrial radiocarbon age calibration, 0-26 cal kyr BP, Radiocarbon, 46(3), 1029-1058. 
Relvas, P., and E. D. Barton (2002), Mesoscale patterns in the Cape São Vicente (Iberian Peninsula) upwelling region, J. Geophys. Res., 107(C10), 3164, doi:10.1029/ 2000JC000456.

Reynolds, L., and R. C. Thunell (1985), Seasonal succession of planktonic foraminifera in the subpolar North Pacific, J. Foraminiferal Res., 15(4), 282-301.

Rios, A. F., F. F. Perez, and F. Fraga (1992), Water masses in the upper and middle North Atlantic Ocean east of the Azores, Deep Sea Res., Part A, 39(3-4), 645-658.

Rogerson, M., E. J. Rohling, P. P. E. Weaver, and J. W. Murray (2004), The Azores Front since the Last Glacial Maximum, Earth Planet. Sci. Lett., 222(3-4), 779-789, doi:10.1016/ j.eps1.2004.03.039.

Rohling, E. J., et al. (2004), Reconstructing past planktic foraminiferal habitats using stable isotope data: A case history for Mediterranean sapropel S5, Mar. Micropaleontol., 50(1-2), 89-123, doi:10.1016/S0377-8398(03)00068-9.

Rousseau, D. D., G. Kukla, and J. McManus (2006), What is what in the ice and the ocean?, Quat. Sci. Rev., 25(17-18), 2025-2030, doi:10.1016/j.quascirev.2006.03.009.

Ruddiman, W. F. (1977), Late Quaternary deposition of icerafted sand in the subpolar North Atlantic (lat $40^{\circ}$ to $65^{\circ} \mathrm{N}$ ), Geol. Soc. Am. Bull., 88, 1813-1827, doi:10.1130/00167606(1977) $88<1813:$ LQDOIS $>2.0$. CO; 2 .

Salgueiro, M. E. C. (2006), Oceanography and productivity conditions on the Iberian margin: A $150 \mathrm{ky}$ foraminifera record, Ph.D. thesis, Univ. Bremen, Bremen, Germany, (Available at http://elib.suub.uni-bremen.de/diss/docs/ 00010538.pdf)

Salgueiro, E., et al. (2008), Planktonic foraminifera from modern sediments reflect upwelling patterns off Iberia: Insights from a regional transfer function, Mar. Micropaleontol., 66(3-4), 135-164, doi:10.1016/j.marmicro.2007.09.003.

Salgueiro, E., A. H. L. Voelker, L. de Abreu, F. Abrantes, H. Meggers, and G. Wefer (2009), Temperature and productivity changes off the Western Iberian Margin during the last 150 ky, Quat. Sci. Rev., in press.

Sanchez, R. F., and P. Relvas (2003), Spring-summer climatological circulation in the upper layer in the region of Cape St. Vincent, Southwest Portugal, ICES J. Mar. Sci., 60(6), 1232-1250, doi:10.1016/S1054-3139(03)00137-1.

Sarnthein, M., K. Winn, J.-C. Duplessy, and M. R. Fontugne (1988), Global variations of surface ocean productivity in low and mid latitudes: Influence on $\mathrm{CO}_{2}$, Paleoceanography, 3, 361-399, doi:10.1029/PA003i003p00361.

Sarnthein, M., et al. (2001), Fundamental modes and abrupt changes in North Atlantic circulation and climate over the last $60 \mathrm{ky}-$ Numerical modelling and reconstruction, in The Northern North Atlantic: A Changing Environment, edited by P. Schäfer et al., pp. 365-410, Springer, Heidelberg, Germany.

Sautter, L. R., and R. C. Thunell (1991), Seasonal variability in the $\delta^{18} \mathrm{O}$ and $\delta^{13} \mathrm{C}$ of planktonic foraminifera from an upwelling environment; Sediment trap results from the San Pedro Basin, Southern California, Paleoceanography, 6(3), 307334, doi:10.1029/91PA00385.

Schiebel, R., B. Schmuker, M. Alves, and C. Hemleben (2002), Tracking the Recent and late Pleistocene Azores front by the distribution of planktic foraminifers, J. Mar. Syst., 37(1-3), 213-227, doi:10.1016/S0924-7963(02) 00203-8.

Schmittner, A. (2005), Decline of the marine ecosystem caused by a reduction in the Atlantic overturning circulation, Nature, 434(7033), 628-633, doi:10.1038/nature03476.
Schönfeld, J., R. Zahn, and L. de Abreu (2003), Surface and deep water response to rapid climate changes at the Western Iberian margin, Global Planet. Change, 36(4), 237-264, doi:10.1016/S0921-8181(02)00197-2.

Schulz, H., M. Bayer, C. Denker, C. Hemleben, M. Martínez Botí, L. D. Numberger, L. Palamenghi, D. Storz, and U. van Raden (2006), F.S. Poseidon Cruise P334, Las PalmasMessina (15.03.2006-03.04.2006), cruise report, 19 pp., Leibniz-Inst. für Meereswiss. an der Univ. Kiel (IFMGEOMAR), Kiel, Germany.

Shackleton, N. J., M. A. Hall, and E. Vincent (2000), Phase relationships between millennial-scale events 64,000 24,000 years ago, Paleoceanography, 15(6), 565-569, doi:10.1029/2000PA000513.

Shackleton, N. J., R. G. Fairbanks, T.-C. Chiu, and F. Parrenin (2004), Absolute calibration of the Greenland time scale: Implications for Antarctic time scales and for $\Delta^{14} \mathrm{C}$, Quat. Sci. Rev., 23(14-15), 1513-1522, doi:10.1016/j.quascirev. 2004.03.006.

Simstich, J. (1999), Die ozeanische Deckschicht des Europäischen Nordmeeres im Abbild stabiler Isotope unterschiedlicher Planktonforaminiferen, D.Sc. thesis, 96 pp., Univ. of Kiel, Kiel, Germany.

Simstich, J., M. Sarnthein, and H. Erlenkeuser (2003), Paired $\delta^{18} \mathrm{O}$ signals of Neogloboquadrina pachyderma (s) and Turborotalita quinqueloba show thermal stratification structure in Nordic seas, Mar. Micropaleontol., 48(1-2), 107125, doi:10.1016/S0377-8398(02)00165-2.

Sousa, F. M., and A. Bricaud (1992), Satellite-derived phytoplankton pigment structures in the Portuguese upwelling area, J. Geophys. Res., 97(C7), 11,343-11,356, doi:10.1029/92JC00786.

Spero, H. J., J. Bijma, D. W. Lea, and B. E. Bemis (1997), Effect of seawater carbonate concentration on foraminiferal carbon and oxygen isotopes, Nature, 390(6659), 497-500, doi: $10.1038 / 37333$.

Stanichny, S., V. Tigny, R. Stanichnaya, and S. Djenidi (2005), Wind driven upwelling along the African coast of the Strait of Gibraltar, Geophys. Res. Lett., 32, L04604, doi:10.1029/ 2004GL021760.

Stuiver, M., and P. M. Grootes (2000), GISP2 oxygen isotope ratios, Quat. Res., 53(3), 277-284, doi:10.1006/ qres.2000.2127.

Turon, J.-L., A.-M. Lezine, and M. Denefle (2003), Land-sea correlations for the last glaciation inferred from a pollen and dinocyst record from the Portuguese margin, Quat. Res., 59(1), 88-96, doi:10.1016/S0033-5894(02)00018-2.

van Aken, H. M. (2001), The hydrography of the mid-latitude northeast Atlantic Ocean-Part III: The subducted thermocline water mass, Deep Sea Res., Part I, 48(1), 237-267, doi:10.1016/S0967-0637(00)00059-5.

Vargas, J. M., J. Garcia-Lafuente, J. Delgado, and F. Criado (2003), Seasonal and wind-induced variability of sea surface temperature patterns in the Gulf of Cadiz, J. Mar. Syst., 38(3-4), 205-219, doi:10.1016/S0924-7963(02)00240-3.

Voelker, A. H. L., M. Sarnthein, P. M. Grootes, H. Erlenkeuser, C. Laj, A. Mazaud, M.-J. Nadeau, and M. Schleicher (1998), Correlation of marine ${ }^{14} \mathrm{C}$ ages from the Nordic seas with the GISP2 isotope record: Implications for ${ }^{14} \mathrm{C}$ calibration beyond 25 ka BP, Radiocarbon, 40(1), 517-534.

Voelker, A. H. L., S. M. Lebreiro, J. Schönfeld, I. Cacho, H. Erlenkeuser, and F. Abrantes (2006), Mediterranean outflow strengthening during northern hemisphere coolings: A salt source for the glacial Atlantic?, Earth Planet. Sci. Lett., 245(1-2), 39-55, doi:10.1016/j.eps1.2006.03.014. 
von Langen, P. J., D. W. Lea, and H. J. Spero (2000), Effects of temperature on oxygen isotope and $\mathrm{Mg} / \mathrm{Ca}$ values in Neogloboquadrina pachyderma shells determined by live culturing, Eos Trans. AGU, 81(48), Fall Meet. Suppl., Abstract OS11C-20.

Waelbroeck, C., J.-C. Duplessy, E. Michel, L. Labeyrie, D. Paillard, and J. Duprat (2001), The timing of the last deglaciation in North Atlantic climate records, Nature, 412, 724-727, doi:10.1038/35089060.

Weinelt, M., M. Sarnthein, U. Pflaumann, H. Schulz, S. Jung, and H. Erlenkeuser (1996), Ice-free Nordic seas during the last glacial maximum? Potential sites of deepwater formation, Palaeoclimates, 1, 283-309.

Wilke, I., T. Bickert, and F. J. C. Peeters (2006), The influence of seawater carbonate ion concentration $\left[\mathrm{CO}_{3}^{2-}\right]$ on the stable carbon isotope composition of the planktic foraminifera species Globorotalia inflata, Mar. Micropaleontol., 58(4), $243-$ 258, doi:10.1016/j.marmicro.2005.11.005.

Wilke, I., H. Meggers, and T. Bickert (2009), Depth habitats and seasonal distributions of recent planktic foraminifers in the Canary Islands region $\left(29^{\circ} \mathrm{N}\right)$ based on oxygen isotopes, Deep Sea Res., Part I, 56(1), 89-106, doi:10.1016/ j.dsr.2008.08.001.

Zahn, R., J. Schönfeld, H. Kudrass, M. Park, H. Erlenkeuser, and P. Grootes (1997), Thermohaline instability in the North Atlantic during meltwater events: Stable isotope and icerafted detritus records from core SO75-26KL, Portuguese margin, Paleoceanography, 12(5), 696-710, doi:10.1029/ 97PA00581. 